\title{
Battle Camp to Boralga: a local study of colonial war on Cape York Peninsula, 1873-1894
}

\author{
Noelene Cole
}

The history of the Cook district in north-eastern Australia illustrates the Queensland government's difficulties in maintaining colonial settlement in the remote north and the determination of Aboriginal people to resist the gold, transport and pastoral frontiers. Expeditions of Kennedy (1848) and the Jardines (1864) foreshadowed disastrous patterns of colonisation on Cape York Peninsula. ${ }^{1}$ In each case the resolve of the intruders, if not their rifle power, was matched by tenacious Aboriginal resistance. William Hann's journey into southern Cape York Peninsula in 1873 was of less epic proportions, but the pattern of conflict with Aborigines was sustained, ${ }^{2}$ and the consequences of the expedition unprecedented. Hann's report of mining potential led to JV Mulligan's discovery of 'payable' quantities of alluvial gold on the Palmer River. ${ }^{3}$ In spite of Mulligan's warnings of 'the great distance, the mighty rivers to cross ... the approaching wet season', and the need for constant vigilance to protect 'the horses and ourselves from the blacks', ${ }^{4}$ the news drew thousands of prospectors from the south and overseas. ${ }^{5}$ In economically depressed Queensland the Palmer gold rush was welcomed as 'salvation'.6

As predicted, the forces of nature and Aboriginal resistance wreaked havoc on the miners. Edward Palmer of Gamboola station later reflected: 'The golden news from the far northern diggings was of a most glittering nature, but there was a reverse side ... in the hardships and privations endured. ${ }^{7} \mathrm{~A}$ major reverse side was the disaster of race relations. Following well-entrenched patterns in Queensland, the process of colonisation became a cross-cultural struggle with the features of a 'situation of war'. ${ }^{8}$

In analysing the nature of the conflict in the Cooktown-Palmer region, historians have identified as key issues:

\footnotetext{
Carron 1849; Jardine 1867.

Hann's diary quoted by Jack 1922 vol I: 406.

Jack 1922 vol II: 412-13, 387.

Mulligan's autobiography quoted by Pike 1998: 13.

The Palmer goldfield had an estimated population of 19,500 in 1877: see Kirkman 1980.

Palmer 1983: 170.

7. Palmer 1983: 154.

8. Evans et al. 1988: 28; see also Cilento and Lack 1959: 203; Fitzgerald 1982: 207; Reynolds 1998: 123 who describe the conflict in this region as 'war'.
} 
- the devastating environmental and cultural impacts of alluvial mining; ${ }^{9}$

- the failure of the Queensland government to avoid an established pattern of conflict; ${ }^{10}$

- the intensity and duration of Aboriginal resistance; ${ }^{11}$

- varied impacts of the mining, transport and pastoral frontiers; ${ }^{12}$

- the role of the Native Mounted Police. ${ }^{13}$

As argued by McKenna, 'The questions asked by historians in the 1970s still need to be asked today'. ${ }^{14}$ Therefore this study extends the research of Hughes, Kirkman and others by focusing on an area between Cooktown and the Palmer River which was profoundly affected by the mining, transport and pastoral frontiers. ${ }^{15}$ It draws on a range of data to review policies, strategies and engagements associated with the process of colonisation in this area from 1873 to 1894 . The strength of resistance provides a central question in this research - which strategies and conditions made Aboriginal resistance so effective?

The study area centres on the old settlement and police camp of Boralga and its sphere of influence which extended from the Laura River to the Kennedy, Normanby and Deighton Rivers, east to the Hell's Gate track and south to Laura (Figure 1). The connections of contemporary Aboriginal people with this area and with stories and people of the 'wild time' motivated this case study. In a community archaeology project, Aboriginal Elders from Laura identified places which they consider to have historical significance: old homesteads, police stations, graves and railway sidings. At a few sites, detailed recording was undertaken, as at Boralga (locally known as 'Brolga'), which is well known to Laura people through their work in the police force and cattle industry. Results of the project were published as an archaeology report which linked the recording of places with family stories. ${ }^{16}$ Background historical research evolved into a deeper investigation - hence this paper. This study is therefore an offshoot of the community project, and as such has been enriched by the shared memories and insights of local people, in particular George Musgrave, Tommy George, the late Mrs George and Danny Banjo.

\section{Before the gold rush}

The rich coastal and riverine environments of tropical Cape York Peninsula supported a large Indigenous population, although population density was lower inland where rainfall is less reliable. ${ }^{17}$ Archibald Meston estimated the Indigenous population in precontact times to be 'probably 20,000' north of the 17 th parallel. ${ }^{18}$ Bruce Rigsby suggested a figure of 'probably less than 10,000 ' ${ }^{19}$ Mike Morwood identified 'high

9. Reynolds 1982: 186 .

10. Kirkman 1978.

11. Rowley 1972; Kirkman 1978; Hughes 1978; Brady et al. 1980; Loos 1982; Reynolds 1982.

12. Eg Hughes 1978; Loos 1982.

13. Loos 1982; Reynolds 2000.

14. McKenna 2002: 32.

15. See Hughes 1978; Kirkman 1978; Brady et al. 1980; Haviland and Haviland 1980.

16. Cole et al 2002.

17. Thomson 1972; Patz 1982; Anderson and Robins 1988; Sommer 1976.

18. Meston 1896: 4. 


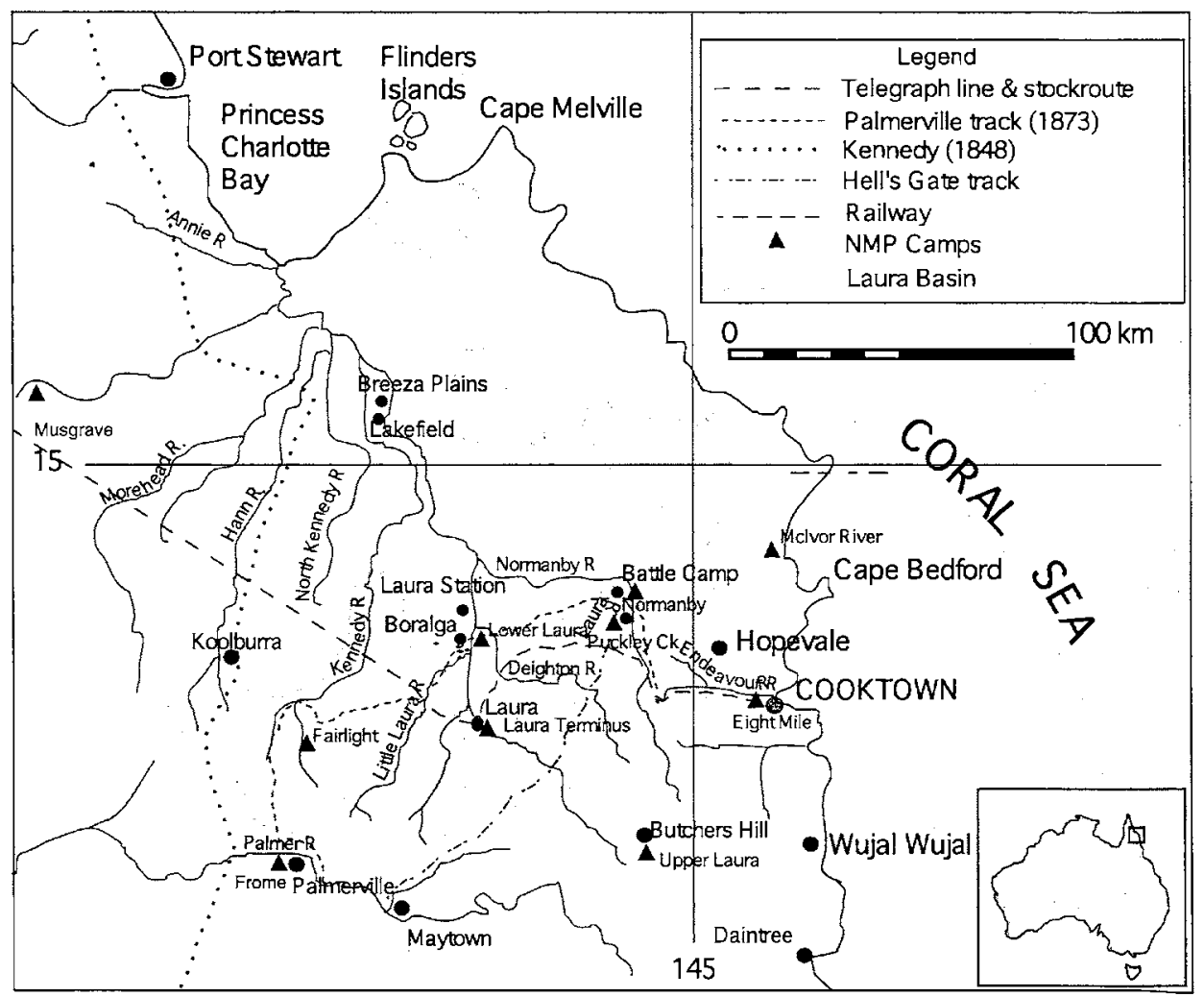

Figure 1: Map of the study area. (Note that the police network altered over the period 1874-1894)

population levels (and) intensive resource use' as features of the recent system of Aboriginal land use in Cape York Peninsula. ${ }^{20}$

At least twelve different languages were owned and spoken by the clans of the region, which includes what is now Lakefield National Park. ${ }^{21}$ Clans were the primary land owning and land using groups, whereas the language-named 'tribes' of today are believed to represent post-contact social formations. ${ }^{22}$ For example, the Kuku Thaypan people are descended from clans who spoke Thaypanic and related languages. ${ }^{23}$ Clans who spoke varieties of Guugu Yimithirr occupied coastal lands north and south of the Endeavour River and west to Battle Camp. ${ }^{24}$ Walter Roth used the term 'Koko Warra'

19. Rigsby 1980: 5 .

20. Morwood 1995: 39.

21. Aboriginal Land Claim to Lakefield National Park 1996 (based on a critical assessment of literature review, ethnographic descriptions by Rigsby and Hafner in the claim books and oral history evidence).

22. Rigsby 2003; see also Aboriginal Land Claim to Lakefield National Park 1996: 1. Haviland and Haviland 1980, map 1; Rigsby 2003.

23. Rigsby 2002: 1 .

24. Haviland and Haviland 1980, map 1; Rigsby 2003. 
to describe 'various mutually-friendly groups of natives wandering over the hinterland south and east of Princess Charlotte Bay, speaking within certain limits similar dialects and practising similar usages and customs' ${ }^{25}$ However, Rigsby has concluded that the term 'Koko Warra' refers to a number of distinct clans and languages such as the Sugarbag Bee language which was spoken towards Laura. ${ }^{26}$ The cultural network included clans of the North Kennedy, Normanby and Laura Rivers, as well as clans who spoke varieties of Guugu Yimithirr, Lamalama, Olkola and Kuku Yalanji languages respectively. ${ }^{27}$ As personal multilingualism was another important regional characteristic, members of the various clans were (and are) able to speak, or at least understand, languages of their neighbours. ${ }^{28}$

The land was organised in hundreds of countries which were owned and used according to a complex system of law, rights, responsibilities and spiritual associations, all of which were vested in clan estates. ${ }^{29}$ Aboriginal people moved within this region in 'appropriate and customary ways'. ${ }^{30}$ Their hunter-gatherer-fisher economies entailed seasonal cycles of activities which were in harmony with the tropical monsoon climate. In the wet season people sought relief from heat, flooding and mosquitoes on the plateaux and ranges, although these upland areas could be visited throughout the year. ${ }^{31}$ The dry season (May to October) was the time of movement, ceremony and social interaction. ${ }^{32}$

The rivers were central to Aboriginal economies and lifestyles. Journals of various European travellers record how, in the rich habitats of the Normanby-North Kennedy river systems, Aborigines caught fish (using traps, 'poison' plants, weirs, nets, spears and hollow logs), gathered foods (such as waterlily roots, shellfish and eggs), hunted animals, constructed huts, burned the grass, followed pathways, made camp fires, cooked in stone ovens and stored their fishing nets, spears, dillybags, clubs and axes. ${ }^{33}$ The high density of Aboriginal settlement is evident in Mulligan's description of 'a regular township' of 'about one hundred gunyahs or more' near the Kennedy River. ${ }^{34}$ Another example is a 'fishing station' on the Normanby River near Battle Camp: 'The blacks must have had a good many large barramundi judging by the heaps of scales lying about. Six dome-shaped gunyahs, 4 feet high and 6 in diameter, were still standing. ${ }^{35}$

Importantly, 'rivers were major corridors or paths of interaction'. ${ }^{36}$ The importance of waterways is reflected in the association of cultural sites with water resources

25. Roth 1910: s.3.

26. Rigsby 2003.

27. Rigsby 2003.

28. Rigsby 1997; Haviland 1979: 32

29. Aboriginal Land Claim to Lakefield National Park 1996; Roth 1910: s.1.

30. Aboriginal Land Claim to Lakefield National Park 1996: 87.

31. Trezise 1971: 7 .

32. Sharp 1939: 255; McConnell 1930: 182.

33. See records of Hann 1873; Mulligan 1873 quoted in Pike 1998: 37-40; Jack 1922 vol II: 474-518; Corfield 1923; Roth 1901: s.15.

34. Mulligan quoted in Pike 1998: 39.

35. Jack 1922 vol II: 488 .

36. Aboriginal Land Claim to Lakefield National Park 1996: 87. 
and the frequency of aquatic motifs (such as fish, crocodiles and freshwater tortoise) in local rock paintings. ${ }^{37}$

The Aboriginal Land Claim to Lakefield National Park has documented the connections of Aboriginal people with the general area of this study. ${ }^{38}$ For example, the Magarrmagarr-warra clan estate took in Boralga. ${ }^{39}$ In 1877 Sub-Inspector O'Connor of the first Lower Laura Native Mounted Police detachment referred to the impressive appearance, prosperity and courage of local Aboriginal people, but made no comment on language/s or identities: 'The Blacks are very numerous and plucky as a race they are tall and well made and fat - they have only the wommera-spear as a weapon of defence or offence, but these they can throw nearly $200 \ldots$ yards. ${ }^{, 40}$

\section{From gold to cattle}

In October 1873 a Queensland government party disembarked at the Endeavour River to journey to the Palmer River to proclaim the goldfields. The group included Northern Roads Engineer A Macmillan, Gold Commissioner H St George, around 90 prospectors and a detachment of Native Mounted Police led by veteran officer Sergeant Armstrong. ${ }^{41}$ The officials were mounted, others were on foot, many in the party were armed.

Charles Heydon wrote to the Sydney Morning Herald in 1874 questioning the methods used in this crucial period, at which point 'permanent relations between the two races were to begin': 'Can it be possible that the leaders had received no instructions as to the treatment of the natives, and the importance of establishing friendly relations and treating them with kindness? ${ }^{42}$ Apparently no such instructions were issued, as can be seen in the progress of St George's expedition.

Events of this journey include the now legendary battle of the Normanby (at Battle Camp). ${ }^{43}$ William Webb, a member of the expedition, described the fate of Aborigines in this unequal combat: 'Thereupon the blacks ran away and were pursued as far as a large lagoon, and all that went there stayed there. ${ }^{.44}$ Later at the Kennedy River: 'A lot of blacks were shot while we were at this camp. I do not know why, as they had not interfered with us. ${ }^{\prime 45}$ Another expedition member, J Hogg, also recalled an attack on 'a big mob of blacks' on the Kennedy River: 'It was decided to disperse them at once and for this purpose the troopers rode ahead. ${ }^{46}$ When Mulligan met fierce Aboriginal resistance on his second Palmer expedition in 1874, the scene was set for

37. Morwood and Hobbs 1995; Cole 1998.

38. Aboriginal Land Claim to Lakefield National Park 1996.

39. Aboriginal Land Claim to Lakefield National Park 1996: 152; B Rigsby, University of Queensland, pers. comm. 2004.

40. O'Connor 1/12/1877 Queensland State Archives (QSA) A/40117 File 1449, 4072/77.

41. Jack 1922 vol I: 418-24; Kirkman 1978; see Blue Book of Queensland 1873 for Armstrong's record of employment in the police force.

42. Sydney Morning Herald 2/2/1874, quoted in Queensland Legislative Assembly Votes and Proceedings (QVP University of Queensland Fryer Library) 1875 vol 1: 620-8; see also

Kirkman 1978: 122-3.

43. Eg see Kirkman 1978: 120-5.

44. Webb quoted in Jack 1922, vol II: 422; see also Hughes 1978; Kirkman 1978.

45. Webb quoted in Jack $1922 \mathrm{vol} \mathrm{II:} 423$.

46. Hogg nd: 203 (John Oxley Library JO). 
war: 'After three times being repulsed ... they made a fierce rush at us as we were leaving the camp. I never saw blacks so determined ... They will however, for the future, know the effect of the rifle in this locality. ${ }^{47}$

Proclamation of the gold fields was followed by the rapid development of roads and settlements to support the diggings. Macmillan's hastily surveyed route became the rush track (Palmerville Dray track). A mail station established at a crossing of the track on the lower Laura River, half way between Cooktown and the Palmer (a distance of some 140 miles or 225 kilometres) became an important staging post. Harry Jones occupied land there at 'Boralga', and opened a public house and butcher's shop. ${ }^{48} \mathrm{Chi}-$ nese market gardens and wet season holding yards for stock were established nearby. ${ }^{49}$ In 1875 a telegraph station was constructed a few miles east of the crossing. ${ }^{50}$

An immediate effect of the gold rush was a boost to the north Queensland cattle industry. ${ }^{51}$ Mobs of cattle were driven north from Mount Surprise, thus extending the industry to the base of Cape York Peninsula. ${ }^{52}$ Palmer noted that 'very few breeding cattle were brought out, but some small runs towards Cooktown were stocked with cattle, the country consisting of open timbered ridges of only a second-class description, but fairly well watered'. ${ }^{3}$

Meanwhile, St George was complaining of inadequate police protection on the goldfields where 50 to 80 new prospectors were arriving every day. ${ }^{54}$ The Cooktown Herald called for more police detachments to prevent attacks and 'atrocious murders' by Aborigines along the routes to the Palmer. ${ }^{55}$ Following the usual Queensland government practice of appointing Native Mounted Police units to 'newly settled country', ${ }^{56}$ a detachment was installed at Boralga by December 1875 (Figure 2). ${ }^{57}$

\section{The settlement of Boralga}

Sub-Inspector O'Connor of the first Lower Laura detachment described the Boralga landscape as:

Very flat, thickly covered in places with cabbage tree - also with numerous large and small lagoons ... with the exception of one or two sand ridges the country is all submerged during the wet season the flood marks ranging on the trees from two to twenty-five feet ... There is no country that can be called good (10) ten miles below these Barracks to the sea on account of its flooded nature. ${ }^{58}$

Historical maps show the features of Boralga - the river, Boralga Swamp, tracks to the Palmer, Jones' Public House (Boralga Homestead), 'Chinese huts', the Police Pad-

47. Mulligan 27 May 1874, quoted in Jack 1922 vol II: 426.

48. 'GP' 1942: 29.

49. Corfield 1923; Stephens 1972; see also Embley's plans 1883 (Queensland Department of Natural Resources DNR).

50. Bradford 1961-62.

51. Palmer 1983: 137; Bolton 1972: 91; May 1983.

52. May 1983: 139; see also Cilento and Lack 1959: 249.

53. Palmer 1983: 141.

54. St George to Sec. Works and Mines 2/4/1874 QSA WOR/A83.

55. Cooktown Herald $11 / 11 / 74$ (JO).

56. QVP 1875, vol 1 Report of Police Commissioner for 1874.

57. Cooktown Herald 1/1/1876; Corfield 1923; Plan of Laura River 1877 QSA A/40117.

58. O'Connor to Police Commissioner $1 / 12 / 1877$ QSA A/40117 File 1449, 4072/77. 


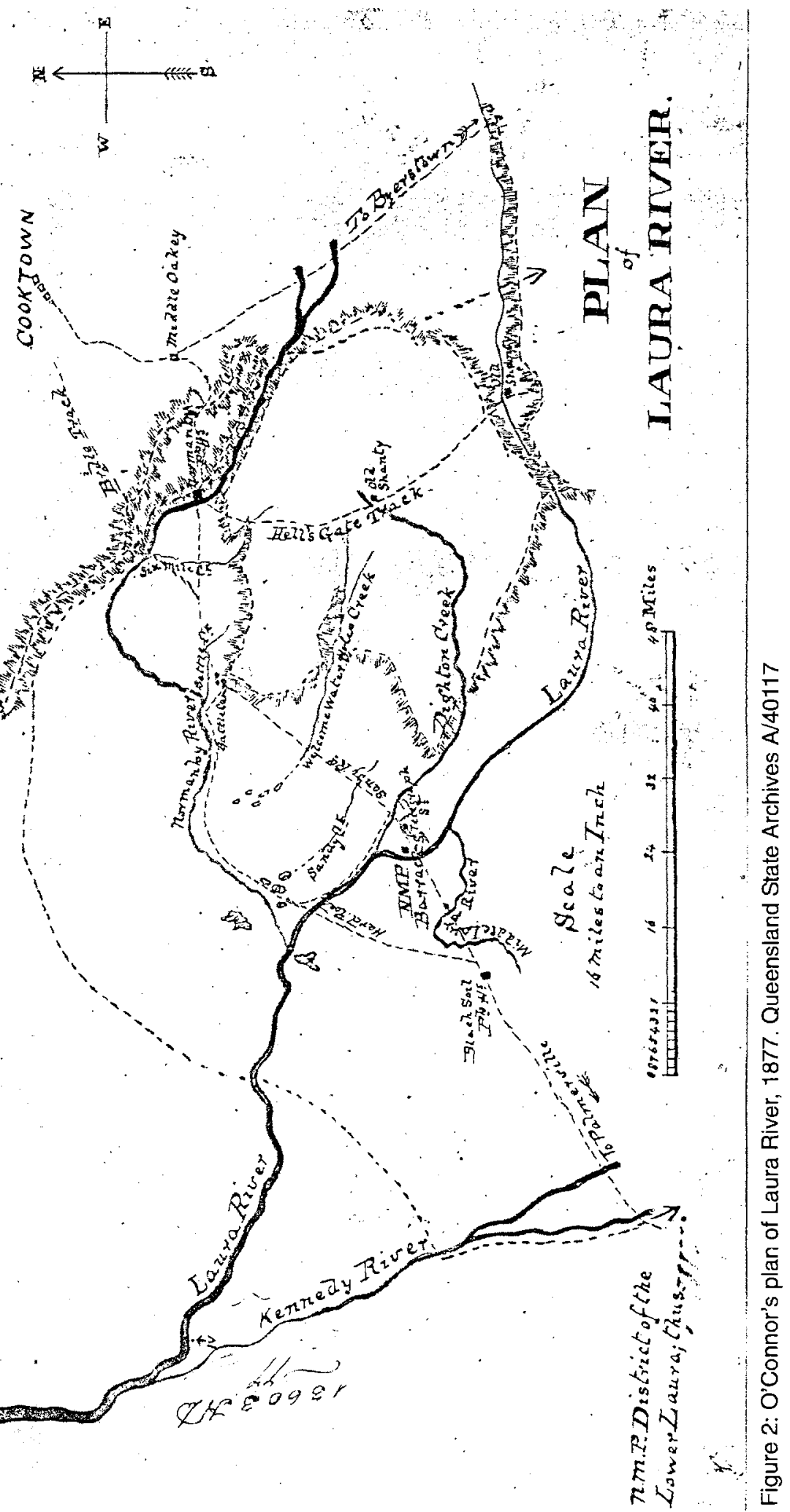




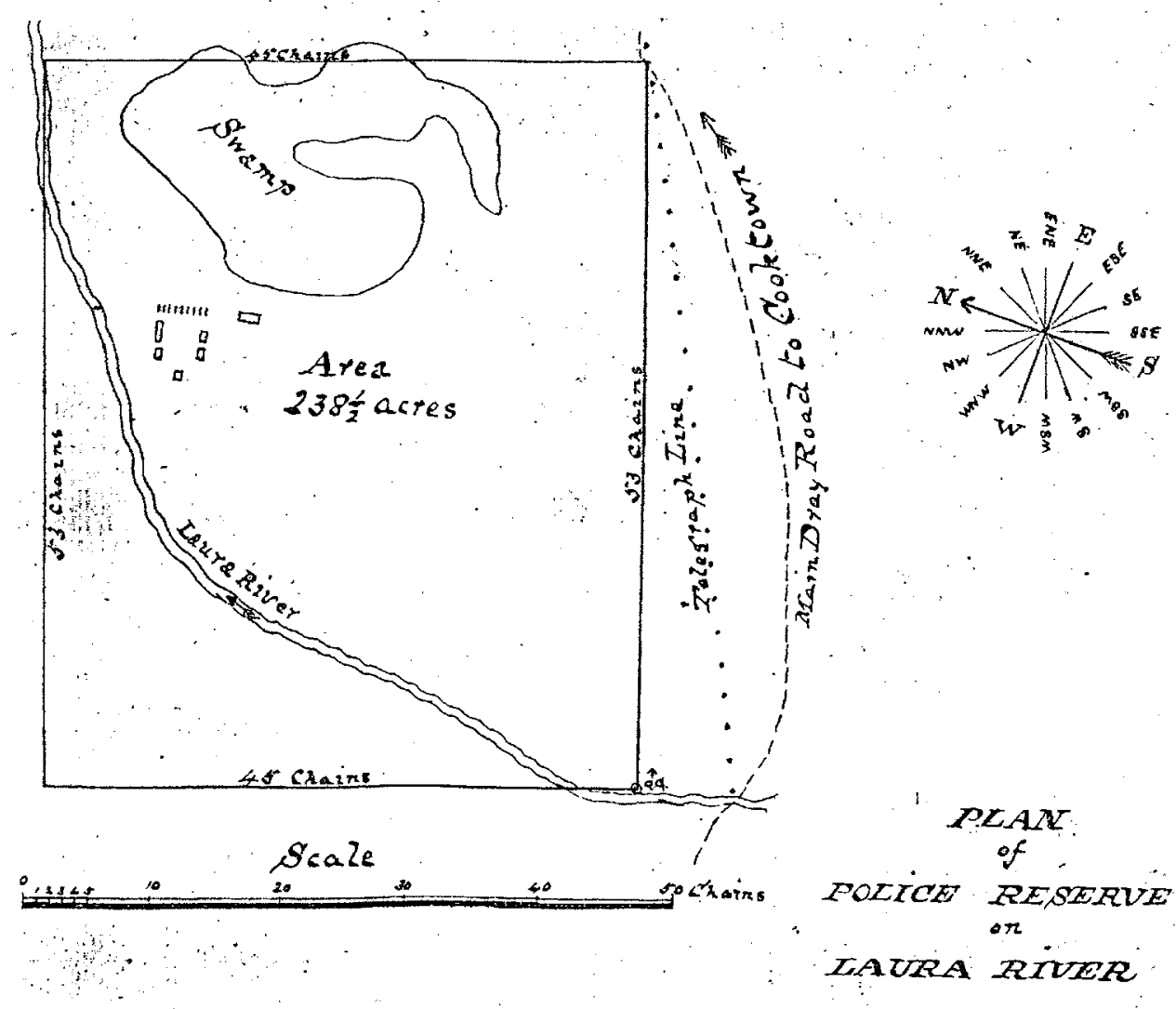

Figure 3: O'Connor's plan of the police Reserve on the Laura River, 1877. Queensland State Archives A/40117

dock, the Native Mounted Police camp and the telegraph office (Figure 2 and 4). ${ }^{59}$ O'Connor's plan of the 'Police Reserve' shows an area of 238.5 acres (96.5 hectares) which extends a little north of the telegraph line to the Laura River, with the police camp and swamp in between (Figure 3). ${ }^{60}$ The substantial nature of the camp is indicated by its scattered remains which were mapped in 2000, confirming general features of O'Connor's 1877 plan (see Figure 5). ${ }^{61}$ The buildings included troopers' huts (Figure 6), ${ }^{62}$ an officer's residence, blacksmith's forge, constable's cottage and store sheds (Figure 7). As well as traces of these structures, the remains include scarred ironwood trees and stone artefacts which may pre-date the police camp. At the periphery of the site a cemetery contains the graves of Alexander Mann, speared by Aborigines in 1875 , and Peter McDermott of Laura Station who died in 1884 after a fall from his horse.

\footnotetext{
59. Eg see Plan of Police Reserve on Laura River, Plan of NM Police Paddock and Plan of Laura River 1877 QSA A/ 40117 File 1449, 4072/77; Plan of Cook district 1883 QSA A/41364.

60. Plan of Police Reserve on Laura River 1877 QSA A / 40117 File 1449, 4072/77.

61. Cole et al. 2002; JO Neg. 57328 may depict the tent phase of the camp.

62. JO Neg. 66439.
} 


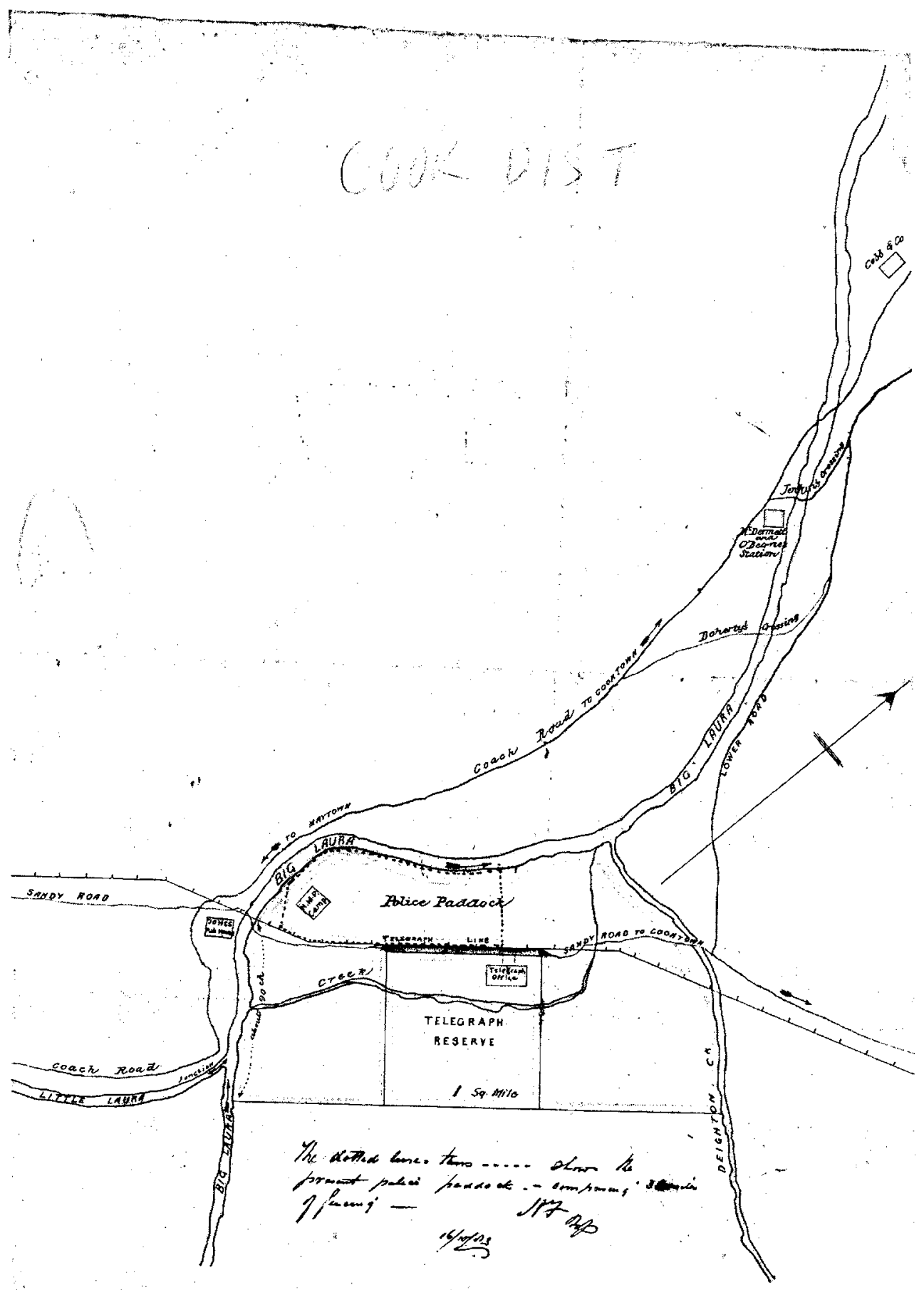

Figure 4: Plan of Cook district showing Laura, Little Laura and Deighton Rivers, police paddock and telegraph reserve, McDermott and O'Beirne's station (Laura station) and various tracks to Cooktown, 1883. Queensland State Archives A/41364 


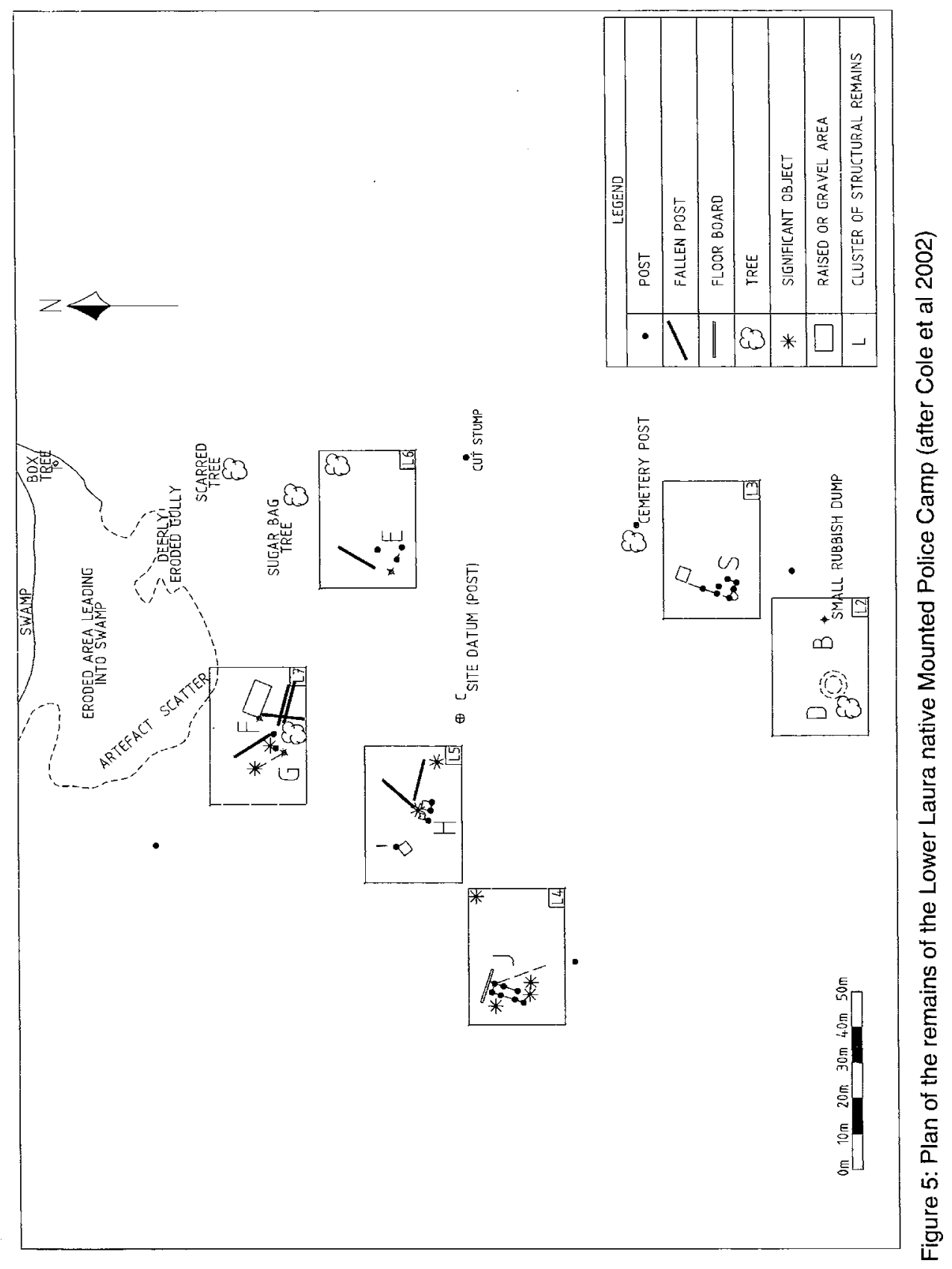




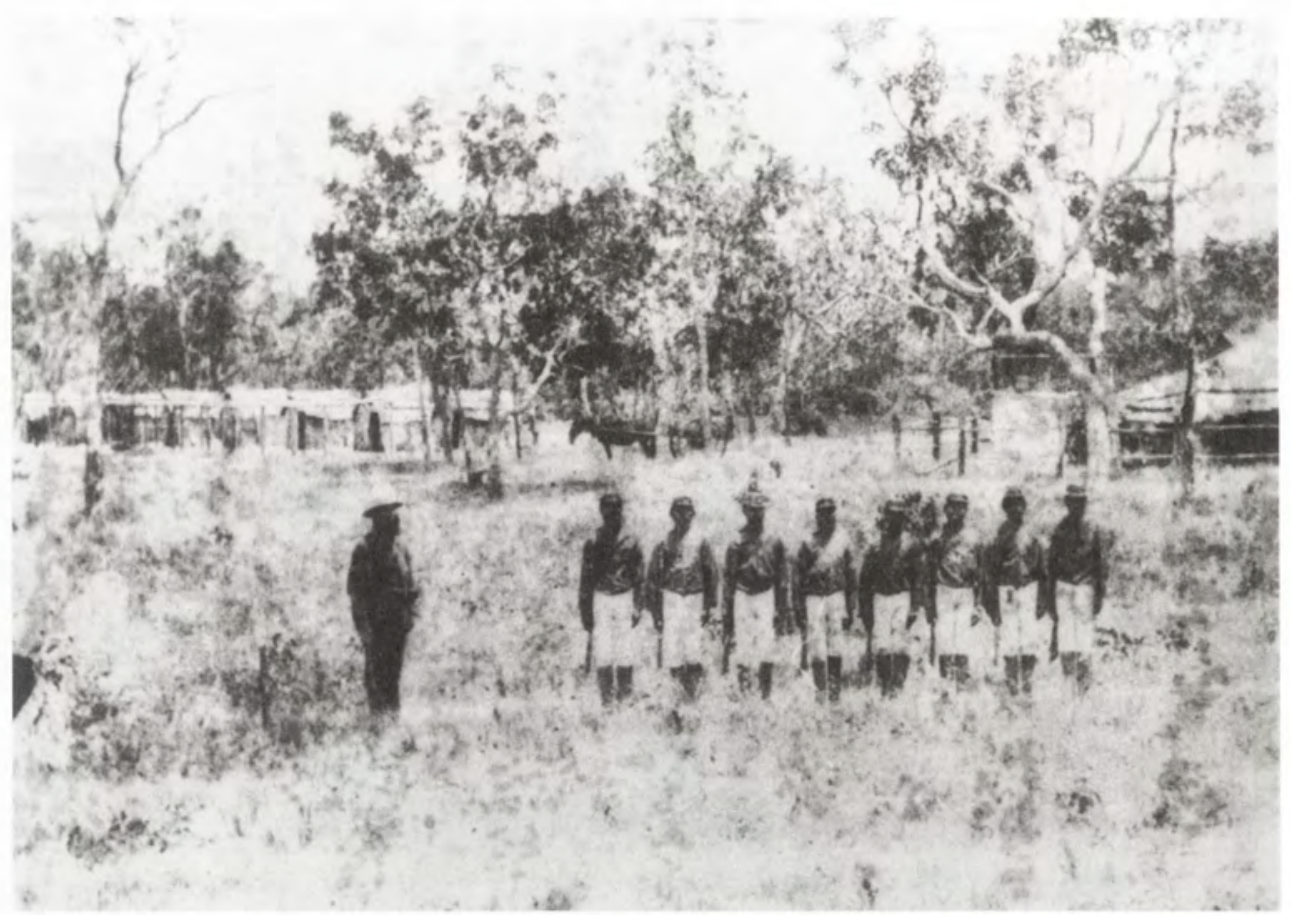

Figure 6 (above): Detachment of Native Mounted Police, Lower Laura. Note troopers' huts in the background. John Oxley Library Neg. 66439

Figure 7 (below): Sub-Inspector Marrett and wife in front of their residence, Lower Laura, c1882. John Oxley Library Neg. 61221 (Marrett collection)

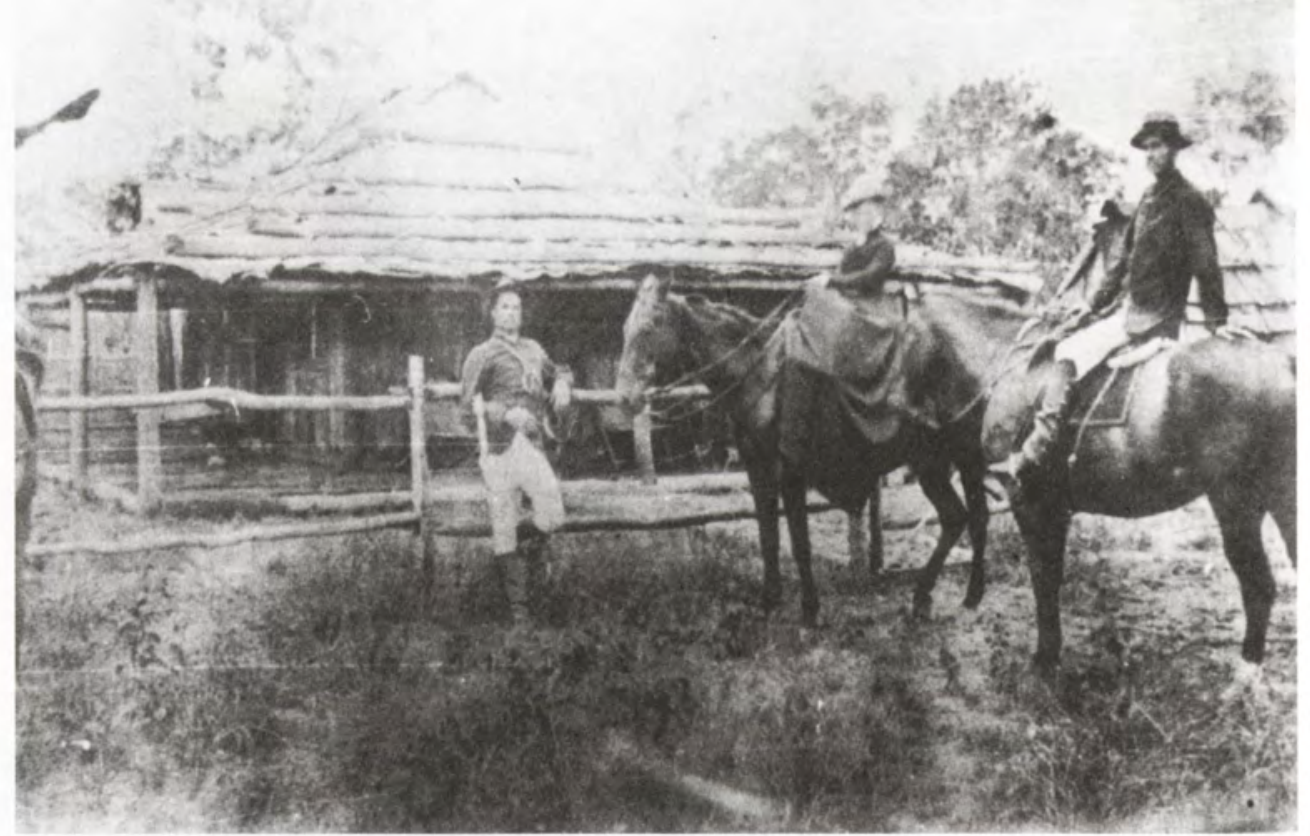


Lower Laura Native Mounted Police camp was staffed by an officer, constable and around eight troopers. ${ }^{63}$ The composition of the detachment in 1884 (a Sub-Inspector, six troopers and 21 horses) altered little over the next decade. ${ }^{64}$ The first Lower Laura troopers were recruited from the south (Fraser Island), ${ }^{65}$ because it was assumed that strangers would be unsympathetic to local Aboriginal people and less likely to desert. In fact, trooper defections were very common in north Queensland. ${ }^{66}$ There were also Aboriginal women and children residing at Lower Laura, and it is likely that they were captured from local Aboriginal groups by the police. ${ }^{67}$ Members of the first Lower Laura detachment achieved some fame when they were sent to Victoria to assist in tracking the Kelly Gang. ${ }^{68}$

Located near a river and a 'fever-ridden swamp', ${ }^{69}$ Boralga required its occupants to endure heat, humidity, floods, mosquitoes and isolation for many months of the year. As mosquito-borne diseases such as malaria (known as 'Gulf' or 'Palmer' fever) were a common cause of illness and death in the settler population, ${ }^{70}$ it is likely that life at Boralga took its toll in terms of health, morale and efficiency.

\section{The pastoral frontier}

The Palmer gold rush was shortlived and by 1879 most of the miners had deserted the region. ${ }^{71}$ Less spectacular gold deposits were eventually mined at Coen, Normanby, Batavia and Alice Rivers, but pastoralism continued as a major focus of European settlement in Cape York Peninsula.

In spite of falling cattle prices at the end of the $1870 \mathrm{~s},{ }^{72}$ there was a flurry of applications to license crown land around the Laura River for pastoral purposes. ${ }^{73}$ Fox Vale on the Little Laura River was licensed in 1877, although the area had been stocked with cattle somewhat earlier. ${ }^{74}$ In 1879 Peter McDermott and Fergus $O^{\prime}$ Beirne were licensed to operate the Laura run and Donald Mackenzie was granted leases at Lakefield in the early 1880 s. $^{75}$ Olive Vale, Battle Camp, Breeza Plains and the Deighton runs were licensed around the same time. ${ }^{76}$ In 1882 Harry Jones applied for a licence for Boralga which he had occupied for some years. ${ }^{77}$

63. Staffing was typical of other police camps: see Queensland Police Department 1982.

64. Seymour to Col. Sec. 20/12/1884 QSA A/40310 Col. Sec. 9064/84; Travelling Inspector report 23/12/1894 QSA A/41364 149S, 01864/94.

65. Corfield 1923: 59.

66. For examples see Corfield 1923: 59; PohIner 1986: 25 quotes Cooktown Courier 25/9/1888; Seymour to Police Commissioner 1/12/1884 QSA A/41614; Hughes 1978: 109.

67. See abductions recorded by Binnie 1944; Jack 1922 vol II: 483; Hogg nd; May 1983.

68. Whittington 1964-65.

69. Queenslander 2/1/1897.

70. Fever was endemic in the white population: see E Maunsell quoted by Holthouse 1985: 1-2; Johnston 1977; Cilento and Lack 1959: 203; Corfield 1923: 70; Lamond to Police Commissioner 18/5/1897 QSA A/41230 06033/97; Lamond to Police Commissioner 19/5/97 QSA A/41230 49S(1) 06088/97; see also Hill 1907: 69; Whittington 1964-65: 515.

71. Kirkman 1978.

72. May 1983: 28.

73. Aboriginal Land Claim to Lakefield National Park 1996: 9-15; Pearce 2000: 25-31.

74. Pearce 2000.

75. Pearce 1998: 33.

76. Pearce 2000: 26-7. 
The completion in 1888 of a railway from Cooktown to Laura Terminus (Laura Government Township) resulted in the decline of the Palmerville track and Boralga. The telegraph office was relocated to Laura which became a transport hub for the Peninsula. Due to pastoralists' agitation about the presence of Aborigines on their leases, the location of the police camp at Lower Laura continued to be strategic into the 1890s. However, in 1894 Lower Laura was closed, ${ }^{78}$ Laura Terminus police station was reopened, and other police camps maintained to protect pastoral interests and sporadic mining enterprises to the north. ${ }^{79}$ The buildings at Lower Laura were dismantled and recycled. Earl later described the abandoned site: 'On the sloping rise on the brink of a fever-stricken swamp, are dotted the derelict huts of a one-time large native police station ... The district became so subdued that the need for the station ceased to exist. ${ }^{\prime 80}$

The land came under various pastoral leasing arrangements before it was included in Lakefield National Park in 1979. In 1972 Ernie Stephens noted that 'few people ... knew of the existence of an old police camp' on the Laura River. ${ }^{81}$ Jerry Shepherd, a police tracker from Laura, guided Stephens to the site where they found 'old yard posts to take rails (and) ... the old posts and ant bed floors of various buildings' ${ }^{82}$

\section{Policing the Cook district}

In the colonial period, Indigenous matters were administered by the Colonial Secretary for Queensland; frontier policy was managed by the Commissioner of Police and enacted by the Native Mounted Police force. ${ }^{83}$ It was understood by the settler community that police were in charge of relations with Aboriginal people. Hence geologist Robert Logan Jack wrote to the Colonial Secretary requesting that 'an officer of native police with a few troopers should accompany the (survey) party for the double purpose of protecting the horses and taking charge of the relations of blacks and whites' ${ }^{\prime 84}$

Composition of the Cook police network varied according to the frontier situation. Over the years, the Cook police district included police camps at Lower Laura, Normanby, Puckley Creek, Upper Laura (Butcher's Hill), McIvor River, Eight Mile, Frome, Coen and Palmerville, all supervised by a District Inspector based in Cooktown (see Figure 8). At least four police camps existed around Cooktown in 1888 - the Eight Mile, Normanby, McIvor and Lower Laura. ${ }^{85}$ Locations were selected for strategic reasons. As with pastoral homesteads, many police camps were situated near rivers or lagoons, ${ }^{86}$ a practice which probably contributed to the high incidence of fever.

77. Jack 1922 vol II: 639 .

78. QSA A/41364 149S.

79. Eg Coen gold fields operated sporadically from 1878: see Bolton 1972: 257-60; Coen police records date from 1890 QSA A $/ 41229$.

80. Queenslander 2/1/1897.

81. Stephens 1972: 1.

82. Stephens 1972: 1 .

83. Queensland State Archives 1994: 1; Loos 1982: 23-7; Queensland Police Department 1982.

84. Jack 1922 vol II: 521 .

85. Nott to Hamilton 19/9/1888 QSA A/41230, 7194/88; Upper Laura Native Mounted Police camp. at Butcher's Hill also existed at the time.

86. Eg see Murray to Police Commissioner 11/12/1890 QSA/A41229-48S, 4392/91. 


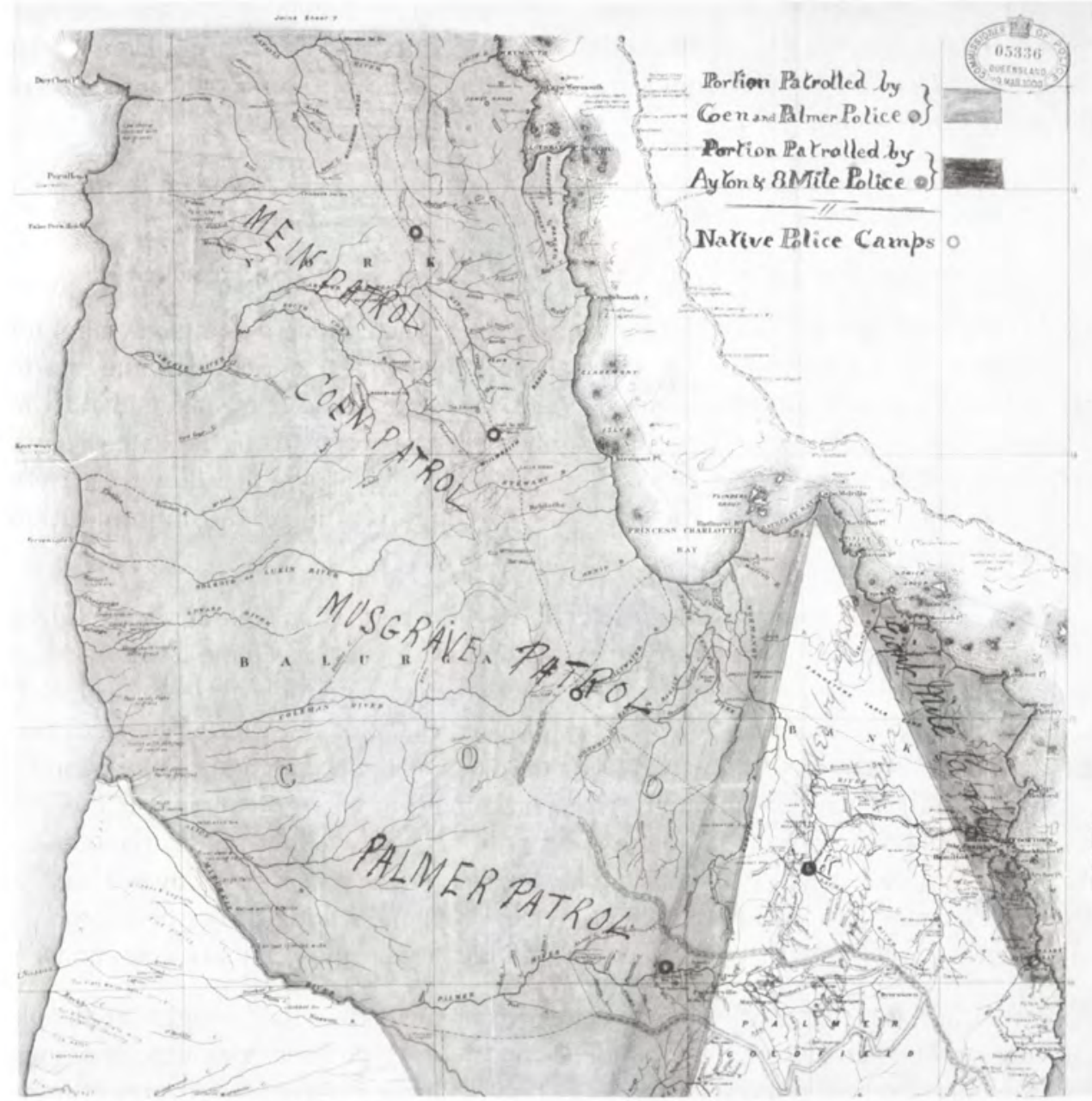

Figure 8: Map of Cook police district showing Native Mounted Police camps, 1900.

Queensland State Archives A/41364

The operation of the police network resembled a military campaign. In dealing with 'depredations' (resistance by Aborigines) 'double' detachments could work together. ${ }^{87}$ 'Flying detachments' could move as required. Equipment and materials were transported from one base to another; camps were closed and reopened, downgraded and upgraded according to the needs for settler protection. The process can be seen in Inspector Murray's recommendations to move the Lower Laura Barracks to the Lower Normanby and the Coen Barracks to Archer River, following his assessment of the pattern of cattle and horse stealing and the location of Aboriginal wet season camps. ${ }^{88}$

87. Travelling Inspector to Commissioner of Police 12/12/1893 QSA A/41364 149S, 12, 435/93.
88. Murray to Commissioner of Police 6/6/1890 QSA A/41229, 7, 389/90. 
Police operations were also based on British military style equipment and routines. ${ }^{89}$ Snider rifles were used throughout the frontier period and Martini Henry rifles were added from $1884 . .^{90}$ Substantial arms were held at Lower Laura even at the end of the police camp's life in 1894:

Arms and Appointments: 12 S.C (Snider Carbines) 4 M.H.C. (Martini Henry Carbines). 3 Revolvers - serviceable.

Ammunition 170 R of S.C 140 R M.H.C and 50 R of revolver - sufficient. ${ }^{91}$

Police uniforms included the distinctive peaked cap which became a symbol for the troopers in local Aboriginal sign language and rock art. ${ }^{92}$ Troopers wore the caps to distinguish them from local Aborigines, as can be seen in a case of mistaken identity at the Lower Laura crossing: WH Corfield, a packer to the goldfields in the Palmer days, described how he was about to fire at Aborigines before realising that they were from the Lower Laura detachment: 'The boy I saw running, went to get his uniform cap to denote a trooper. 93

Official records are sparse for the early frontier period, but the paper trail does indicate the efforts and resources required to operate in such a remote location. Most records relate to the construction of buildings and fencing, and the maintenance of staff, uniforms, stock, firearms and ammunition, drays, boats, ploughs, saddlery and forges. Multiple records survive of minor transactions such as the acquisition of blacksmith's bellows. ${ }^{94}$ Sadly, such accountability was not applied to core operations such as the activities of police patrols. ${ }^{95}$ Although we cannot be sure whether policy, remoteness and/or natural disasters are responsible for the lack of key records for Lower Laura, a similar deficiency has been identified elsewhere. ${ }^{96}$ The 'breaking up' of police camps appears to have complied with the secretive, military style ethos of police operations.

Although it is difficult to track frontier engagements in detail, insights are available in a scattered archive of correspondence and reports, personal memoirs, drawings and photographs, newspapers, journals and books. However, witness accounts of frontier conflict may vary, as in reports of Battle Camp ${ }^{97}$ and the Strau murders. ${ }^{98}$ Some newspaper accounts appear to repeat events already reported, possibly to keep the pot of racial conflict on the boil. Hughes argues that the editors 'believed they were involved in a state of open warfare', a belief which would have contributed to a sense of fear in the settler community. ${ }^{99}$

89. See Lamond 1949: 32; for typical equipment see Travelling Inspector report 23/12/1894 QSA A/41364 149S, 01864/94.

90. QVP vol 1 1875: 617; QVP vol 1 1885: 543.

91. Travelling Inspector report 23/12/1894 QSA A/41364 149S, 01864/94.

92. Trezise 1971: 19.

93. Corfield 1923: 70.

94. See QSA A/41364 149 S

95. Queenslander 1 May 1880: 560; Reynolds 1998: 111.

96. See Lamond 1949; Mulvaney 1989; Reynolds 2000; Fitzgerald 1982.

97. For Battle Camp see Kirkman 1978; Hughes 1978.

98. Eg Cooktown Herald 21/10/1874; Corfield 1923; 'GP' 1946; 'Sundowner' 1947; Hughes 1978: 110; Shay and Shay 1995 discuss the Strau inquest.

99. Hughes 1978: 100 . 


\section{Bush patrols}

Lower Laura camp was located strategically close to the roads, telegraph and cattle stations which it was required to protect. However, movements beyond Boralga were limited by the severe climate and terrain. O'Connor noted that the country downstream was 'impassable for nearly five months' of the year. ${ }^{100}$ The lack of natural pastures in the dry season meant that stock feed had to be imported and travel was restricted. ${ }^{101}$ The difficulties are evident in a report of a patrol to Laura: 'Several miles of this patrol travelled on foot - horses being in too poor condition to carry us and country almost destitute of grass the whole way' ${ }^{102}$ Rocky ground and sharp wattle tree stumps created treacherous conditions for horses, especially in the plateau country to the east. ${ }^{103}$ Protection of the Hell's Gate track located some 36 miles away would have been limited by such factors. ${ }^{104}$ As Lower Laura police were expected to patrol a vast pastoral district which extended north to Breeza Plains, south to Maytown and west to the Kennedy River, they were hard pressed to visit cattle runs several times a year. ${ }^{105}$

Native Mounted Police detachments could be commissioned as escorts or to protect travellers 'who had a reasonable claim' ${ }^{106}$ However, the core duty was to conduct 'bush patrols' to contain Aborigines. These forays were often in response to settler complaints of 'depredations' in which case Aborigines were vigorously pursued, sometimes over long distances, and 'dispersed', ie shot. WH Corfield's description of the Lower Laura detachment 'dispersing blacks' at the Kennedy River reflects the brutality of most accounts. ${ }^{107}$ Aborigines allegedly responsible for killing two of Corfield's horses were tracked for days by the detachment with O'Connor, Corfield and a corporal bringing up the rear. After they had finished shooting, the assailants set fire to the Aborigines' possessions (spears, woomeras and dillybags). It appears that the sole survivors of the group pursued were some old women 'who had knocked up the previous evening and could not make the camp' ${ }^{108}$

O'Connor was reportedly involved in the massacre of Aborigines at Cape Bedford 'in retaliation for the near fatal spearing of two whites'. ${ }^{109}$ The incident was investigated by Bishop Hale of the Aboriginal Commission and later by journalist $R$ Spencer Browne. ${ }^{110}$ An earlier reprisal led by Inspector Coward to avenge the Strau murders was reported by the Cooktown Herald. ${ }^{111}$ Some years later this was described as the 'second battle of Battle Camp'. ${ }^{112}$

100. O'Connor to Police Commissioner 1/12/1877 QSA A / 40117 File 1449, 4072/77.

101. See Travelling Inspector report 23/12/1894 QSA A/41364 149S, 01864/94.

102. Garroway to Police Commissioner 22/11/1904 QSA A/41596, 18594/04.

103. G Musgrave (Kuku Thaypan Elder), Ang-grarra Aboriginal Corporation, pers. comm. 1999.

104. See O'Connor to Police Commissioner 1/12/1877 QSA A / 40117 File 1449, 4072/77; see also plan of Laura River 1877 QSA A/40117.

105. Police Commissioner to Col. Sec. 20/12/1884 QSA A/40310 Col. Sec. 9064/84.

106. Hill 1907: 75; Jack vol II: 522.

107. Corfield 1923: $62-4$.

108. Corfield 1923: 64 .

109. Hughes 1978: 11 cites Brisbane Courier 1/3/1879 which reported 24 Aborigines killed; Kidd 1997: 354 cites R Spencer Browne 1927 who reported 31 killed.

110. Hughes 1978: 111; Kidd 1997: 28; Pohlner 1986: 26, 28.

111. Cooktown Herald 28/10/1874; see also Corfield 1923.

112. 'GP' 1944: 37; 'GP' 1946: 23. 
Willy Long of Laura related how his parents survived an attack on Olkola people led by the 'officer in charge of Musgrave police station'. ${ }^{113}$ As in other incidents in which peaceful rivers and lagoons were turned into massacre sites, ${ }^{114}$ Aborigines fled to a swamp where they were shot. The victims may have belonged to one of five camps in the Coen area reported to have been massacred in 1889 by a formidable force of forty, comprising three police detachments and volunteers led by Sub-Inspector Urquhart. ${ }^{115}$ Such reprisals continued until at least 1896, as indicated by Culpin's account of events which followed the death of pastoralist Mackenzie: '[The Aborigines] were tracked to a camp on the Normanby river, where a good many found a final resting place' ${ }^{\prime 116}$

A feature of police patrols was the abduction of Aboriginal women and children, a practice which was an ongoing source of 'trouble between whites and blacks'. ${ }^{117}$ Harry Mole (who later became a police tracker at Laura) ${ }^{118}$ was 'brought in as a child by members of a punitive expedition who had slaughtered virtually all of his people, the GuguWarra tribe' ${ }^{119}$ The attack took place at Jack Lakes, north of Boralga. ${ }^{120}$ Corfield described how his friend Sub-Inspector O'Connor captured an Aboriginal boy of about six years of age while 'dispersing some blacks'. ${ }^{121} \mathrm{O}^{\prime}$ Connor 'gave' the boy to Corfield. The manager of Rocklands station near Camooweal obtained a child in a similar manner:

One of my boys named Oscar, this boy I got at Cooktown in 1887 \& he has been with me ever since \& when I got him he was a thorough myall ... he was somewhere about 9 or 10 years of age then ... the police got him for me. ${ }^{122}$

\section{Justice on the frontier}

Kirkman has shown that, from the gold rush days, police used confrontational methods to manage race relations. ${ }^{123}$ The approach is illustrated in JH Binnie's account of police terrorising Aborigines in the Palmer days:

The police and black trackers would go out immediately and round the distant tribe - usually about 100 in number. They generally had to do some shooting when they first met the mob to frighten them; then they would get two girls and tie each one to a tree, about 100 yards apart, and keep them tied up until they both told the same story about the crime. ${ }^{124}$

Parry Okeden's 1897 report reveals that the approach was retained over two decades: '[The Native Mounted Police] has apparently confined its operations to retalia-

\footnotetext{
113. Trezise 1969: 102.

114. Corfield 1923; Culpin 15/5/1896 in Mackeith 1987: 88; Mulligan quoted in Pike 1998; Trezise 1969; Strang 1997: 19.

115. Cooktown Courier 14 May, 18 June, 1889 quoted by Loos 1982: 61.

116. Culpin 15/5/1896 in Mackeith 1987: 88.

117. Jack 1922 vol II: 483.

118. Malone to Police Commissioner 26/9/1911 QSA A/44857.

119. Trezise 1969: 51.

120. Haviland and Hart 1998: 36 note stories of regular police raids on the Muunthi-warra at the Jack River.

121. Corfield 1923: 59.

122. McKenzie and Cooper 2001: 158.

123. See Kirkman 1978: 122-4.

124. Binnie 1944: 11-12 (Binnie wrote of his life on the Palmer 1876-82).
} 
tory action after the occurrence of outrages and seems to have dropped all idea of employing only merely deterrent or conciliatory methods'. ${ }^{125}$

If police attempted conciliation they were likely to be met with vigorous local opposition. For example, Sub-Inspector O'Connor (of Lower Laura) was criticised in the Cooktown Courier for negotiating with Aborigines in 1879,126 a strategy which was rendered virtually impossible by the attitudes of pastoralists. The situation is reflected in a complaint made in 1884 by the District Police Inspector to the Police Commissioner in a letter which defends Sub-Inspector Marrett against pastoralists' allegations of inefficiency: 'It is utterly hopeless for him (the Inspector) to expect the good feelings of the majority of his neighbours - humanity is unrecognised - their creed extermination of the natives. ${ }^{127}$

In the same vein Police Commissioner Seymour advised the Colonial Secretary that the pastoralists expected police 'to pursue and shoot down' Aborigines who speared or disturbed cattle. ${ }^{128}$ In 1885 Seymour indicated that he recognised the reasons for Aboriginal resistance in the Cook district, but it appears that government policy was untransformed by this report:

The condition of the blacks on the coast and in the interior of the Cook district has been a matter of some concern. Settlement has advanced on the tribes so rapidly that they have lost their hunting grounds and have been deprived of the only means of existence. The consequence has been the committal of depredations requiring that many complaints have reached the Department. ${ }^{129}$

As British subjects, Aboriginal people were entitled to the protection of the law, ${ }^{130}$ but, as (later) admitted by the police, they 'probably were hunted whenever seen'. ${ }^{131}$ Settlers usually took the law into their own hands, apparently secure in the knowledge that they were immune from prosecution. ${ }^{132}$ After Logan Jack's request for a police escort was refused, he engaged 'boys' who, he claimed, shot and killed two Aborigines near the Normanby in 1879. ${ }^{133}$ Jack later wrote: 'I hold myself free of responsibility for what happened when we were forced to take the law into our own hands' ${ }^{134}$ Pastoralist Edward Palmer stated that 'The white pioneers were harder on the blacks in the way of reprisals when they were forced to deal with them for spearing their men or their cattle or horses even than the Native Police'. ${ }^{135}$ Pastoralists used poisons as well as rifles to kill Aborigines, ${ }^{136}$ as indicated in reports of multiple Aboriginal deaths caused by the consumption of poisoned food obtained from cattle stations. ${ }^{137}$

125. QVP 1897 vol 11: 16

126. Cookfown Courier 25/1/1879 cited by Kirkman 1978: 135.

127. H Fitzgerald to Commissioner of Police $5 / 3 / 1885$ QSA COL/A422, 1840/85, quoted by Haviland and Haviland 1980: 122; see also QSA A/40310 Marrett, CB Police Staff file.

128. Seymour to Col. Sec. 20/12/1884 QSA A/40310 9064/84 Col. Sec. 9064/84.

129. QVP 1885 vol I: 543.

130. See Kidd 1997: 3 .

131. Garroway to Roth 14/7/1900 QSA A/41596, 30/1900.

132. Evans 1999: 189 notes that Aborigines were unable to act as witnesses in Queensland law courts until 1887.

133. Jack 1922 vol II: $488,522$.

134. Jack 1922 vol II: 522 .

135. Palmer 1983: 213.

136. See also Loos 1982: 57,61 . 
From the gold rush days, Aboriginal children and adults were kidnapped to be exploited by settlers for labour and/or sexual purposes. Carriers to the goldfields were said to be serious offenders, ${ }^{138}$ pastoralists pressured police to round up Aborigines for station work, ${ }^{139}$ and Cooktown residents conspired with settlers 'in outside districts' to abduct Aboriginal children. ${ }^{140}$ Roth noted that the latter practice had been 'going on for years, and with the exception of one or two cases ... without good result to the children' (as) 'prostitution and disease usually follow'. ${ }^{141}$

Official policy stated that 'In every case the same law applies to blacks as to white and if the officers go beyond the law they do so at their own risk' ${ }^{142}$ However, Laura school teacher Millais Culpin portrays a prejudiced system which was at one with the racist attitudes of the settler community:

The police now after this tribe will report to headquarters that they 'dispersed' the niggers but will give no real account of the affair. If some busybodies down South were acquainted with the affair the police would probably be tried for murder. If a nigger kills a white man \& is brought up in the Supreme Court he is almost sure of acquittal. Then the usual plan is for the police to escort him back to his country \& accidentally 'lose' him on the road, so that justice is done in spite of the law. ${ }^{143}$

In the 1890s the Aboriginal child known as Oscar of Cooktown drew a picture of Aboriginal prisoners chained to a tree. ${ }^{144}$ As late as 1899 police complained of the absence of a cell at Laura where prisoners were chained to a tree, sometimes for two days. ${ }^{145}$ In 1913 Ethel Culpin wrote that the 'native 'Lock up' is very crude - Built of timber - the prisoners are chained up inside'. ${ }^{146}$ Apparently the structure was gone by 1924 when a traveiler recorded that Laura '[had] no lock-up, only a yard where native prisoners were chained to trees. ${ }^{\prime 147}$ The practice of chaining Aboriginal prisoners was retained well into the 20th century, as George Musgrave (now over eighty years of age) recalls seeing Aborigines forced to walk 'in chains' across the Peninsula. ${ }^{148}$

\section{Resisting the frontier}

The establishment of Boralga near important waterways followed a characteristic pattern of colonial settlement that inevitably provoked conflict with Aboriginal land owners. However, the tragic outcomes of the battle of the Mitchell River and Battle Camp demonstrated the futility of open combat against mounted opponents with high powered guns. Instead, Aborigines waged guerrilla warfare to target the Palmerville

137. Aboriginal Land Claim to Lakefield National Park 1996, Jack Harrigan transcript p 111; Culpin 15/ 5/1896 in Mackeith 1987: 88; see also Loos 1982: 57, 61.

138. Loos 1982: 79.

139. Brooke to Fitzgerald, 31/12/1882 QSA COL/A356, 1303/1883, quoted by Haviland and Haviland 1980: 124.

140. Haviland and Haviland 1980: 134.

141. Roth (1902) 1903, quoted by Haviland and Haviland 1980: 134.

142. Seymour to Colonial Secretary 20/12/1884 QSA A/40310 Col. Sec. 9064/84.

143. Culpin 15/5/1896 in Mackeith 1987: 88; see also Mackeith's note p 10.

144. Mackenzie and Cooper 2001: plate 9.6 .

145. Twaddle to Sub-Inspector, Cooktown 23/1/1899 QSA A/41364 148S 168,99/99.

146. See Mackeith 1987: 97.

147. Brady 1924: 222.

148. Cole 1999. 
Track and Douglas' Hell's Gate track (a pack track to the gold fields used from March 1874). Miners, teamsters, lone and group travellers and their stock were vulnerable, particularly at night when packs, tents and drays provided poor protection from spears which could be projected with accuracy and force from some distance. Aborigines laid ambushes by rolling logs across tracks and planting stakes in wheel tracks. ${ }^{149}$ The Cooktown Herald opined that miners were having to "enter into guerrilla warfare, and risk their lives against the sable foes, who were immeasurably their superiors in tactics and bush fighting' ${ }^{150}$ Such tactics were extremely effective on the remote Hell's Gate track where, according to Mulligan, 'Many a Chinaman and many a white man lost his life ... by the blacks'. ${ }^{151}$

At the Lower Laura crossing, Aborigines attacked from the cover of dense vegetation on the river banks. Mail contractor John Hogsfleisch, who operated a mail station at Boralga crossing before the establishment of the police camp, was said to have been attacked by Aborigines at the crossing on at least two occasions. ${ }^{152}$ The Cooktown Herald wrote that during one such 'ambush', 'Hogsflesh' (sic) was forced to flee, 'the blacks having taken possession of the river and its banks'. ${ }^{153}$ Alexander Mann (buried in Boralga cemetery) was fatally speared in the area in February 1875. In January 1876 the Cooktown Herald was pleased to report that, as part of an upgrade in the capacity of the Native Mounted Police force 'in accordance with our frequent and urgent arguments to that effect', Sub-Inspector $O^{\prime}$ Connor was to be installed with troops 'at the Laura' which, according to the Herald, 'had been made such a notoriously noted spot by the attacks and outrages of the blacks'. ${ }^{154}$

\section{Adapting European materials}

As early as 1874-75, Aborigines had used steel to manufacture axes, spear points and digging sticks and glass to fashion flakes and blades. ${ }^{155}$ In $1877 \mathrm{O}^{\prime}$ Connor observed: 'They have tomahawks made of all kinds of iron such as: bolts, pieces of tines (sic), guard irons - old chisels. ${ }^{156}$ In Aboriginal camps $\mathrm{O}^{\prime}$ Connor found 'different parts of European clothing; legs of trousers, sleeves of coats etc, made into dillybags'. ${ }^{157} \mathrm{Mulli}$ gan reported the use of 'tomahawks made out of one inch iron' on 'Kennedy country', 158 and ironwork was stripped from European graves at Boralga. ${ }^{159}$ Telegraph wire removed by 'the blacks at the Laura on the old Palmerville Road' may have been used to make spear points. ${ }^{160}$ Jack noted the ingenuity with which Aboriginal people recycled materials: 'As a rule, the natives fashion, with infinite pains, such inconsidered

149. Cooktown Herald 21/10/1874.

150. Cooktown Herald 24/6/1874 cited by Reynolds 1982: 112.

151. Mulligan quoted in Pike 1998: 94.

152. Strike 1988: 2 quoted the Cooktown Herald 3/2/1875 and Cooktown Courier 12/6/1875 (Barry Strike is a descendant of J Hogsfleisch).

153. Cooktown Herald 3/2/1875.

154. Cooktown Herald $1 / 1 / 1876$.

155. Hann 1873; Hogg nd; Cooktown Herald 11/11/1874.

156. O'Connor to Police Commissioner 1/12/1877 QSA A/40117 File 1449, 4072/77.

157. O'Connor to Police Commissioner 1/12/1877 QSA A/40117 File 1449, 4072/77.

158. Mulligan quoted by Pike 1998: 39.

159. Stephens 1972.

160. Cooktown Courier 25/1/1879; Coen residents claimed that Aborigines removed telegraph wire to make weapons, QSA A/41229, 4553/91. 
trifles of old irons and shovels, broken pick-heads, scraps of iron hoops, ship's bolts, telegraph wire, cart-wheel tires and the like into weapons and implements, with which they perform prodigies in the way of tree-felling, etc. ${ }^{161}$

Although such adaptations delivered economic benefits, their cultural impact is unknown. It is possible that this was significant, given the social effects of the displacement of stone axes by steel axes in Yir Yiront culture of western Cape York Peninsula. ${ }^{162}$ The appearance of stencilled steel axes and paintings of pigs, horses and policemen in Laura rock art represented innovations which pointed to significant cognitive adjustments as Aboriginal society was confronted with exotic species and materials and a new world order. ${ }^{163}$

\section{Secret strategies}

Aboriginal elders have explained that sorcery paintings played a role in the war against the police. ${ }^{164}$ In one powerful composition, 'lines drawn from the head of a repainted snake to the foot of one police painting were said to put the poison in the policeman'. ${ }^{165}$ In another, a figure of a policeman is depicted in a prone position (a sign of death) as if he had been thrown from his horse. Recently, Aboriginal elders of the Laura district recorded stories of the 'wild time' which relate how other secret strategies were used by Aborigines to outwit the police. ${ }^{166}$

\section{Resisting pastoralism}

Pastoralists had selected the best areas, constructed homesteads on prime water frontage, and were determined to exclude Aborigines, although this was illegal according to licence conditions. The fearful reactions of Aboriginal people encountered in 1879 by Logan Jack near the Normanby River point to the perilous nature of their situation. ${ }^{167}$ The impact of virtual exclusion from important water resources was particularly severe in a region of erratic, monsoonal rainfall. Water holes were polluted by stock, ${ }^{168}$ and customary subsistence activities around rivers and lagoons were disrupted, as were hunting and land management practices such as grass firing on the alluvial plains. ${ }^{169}$

In response, Aboriginal people were driven to make greater use of the semi-arid plateau country which they had occupied periodically for thousands of years. ${ }^{170}$ Here there are springs associated with sandstone aquifers, spacious rock shelters and a variety of plant resources, some of which, like figs and nonda plum, are available in the dry season. ${ }^{171}$ These rocky refuge areas were beyond the range of police in the dry season

161. Jack 1922 vol II: 502.

162. Sharp 1952.

163. Cole 1995.

164. Trezise 1968, 1985; see also Loos 1982; Cole 1995.

165. Trezise 1993: 51.

166. Cole 1999.

167. Jack 1922 vol II: $486,488,491,494$.

168. Binnie 1944: 12 notes water pollution by cattle.

169. For evidence of Aboriginal use of aquatic foods see Hann 1873; Mulligan quoted in Pike 1998; Jack 1922; Corfield 1923; importance of grass firing is noted by Mulligan, quoted in Pike 1998: $109-10$.

170. Morwood and Hobbs 1995; Cole 1998.

171. Morgan et al. 1995: 13; Morwood and Hobbs 1995. 
due to lack of feed for horses and in the wet due to boggy conditions. ${ }^{172}$ The remoteness from settler activities is evident in Mulligan's observation of 1881: 'There is a lot of useless country lying between the Normanby and Laura Rivers, and the Cooktown and Palmer Roads. I question if any white man has ventured over this; the Native Police may have done so. ${ }^{173}$

In the 1880s, it is likely that Aboriginal clans depleted by 'dispersals' and abductions were reduced to smaller, fewer and less viable groups. Apparently Aboriginal people still moved around Boralga, ${ }^{174}$ but their strategic use of the upland areas became critical to survival, as indicated in oral history and archaeological evidence which testify to the sustained use of this country in the post-contact period. ${ }^{175}$ Mulligan, who journeyed along Hell's Gate track in the early 1880s, made a series of important observations which support this evidence.

In 1881 Mulligan noted that the Aborigines had 'taken possession of' the rugged plateau lands in between the Normanby and Laura Rivers:

There can have been nobody along it for years, judging by the way the blacks have taken possession of it now. In many places they have built little townships right on the road, and have the highway blocked frequently by trees chopped down for 'sugarbags'. Their tracks and tomahawks brands are plentiful, but they themselves keep under cover. ${ }^{176}$

Further along the track Mulligan observed:

This is a great stronghold for the blacks, judging by their camps and late tracks. To-day there seemed to be plenty of water in places that were bar-bound, at which the darkies camp, and no doubt find this a good refuge for them. ${ }^{177}$

Mulligan returned to Hell's Gate track in 1883:

Up on top of this tableland, rough as it was, it was actually alive with kangaroos and wallabies, and also blacks, who had regular townships along Hell's Gate Track. This was a great rendezvous for the blacks. The rough nature of the country and the plentifulness of the marsupials was quite what they wanted, seeing that there was no longer traffic on Hell's Gate Track. ${ }^{178}$

\section{Cattle hunters}

Aborigines had speared horses from the gold rush times, a strategy which was described by the Cooktown Herald as an 'outrage' ${ }^{179}$ With the expansion of pastoralism, cattle hunting became an important resistance strategy. ${ }^{180}$ Parry-Okeden noted

172. See Seymour to Colonial Secretary 20/12/1884 QSA A/40310 9064/84 Col. Sec. 9064/84; Fitzgerald to Police Commissioner 5/3/1885 QSA COL/A422 1840/85.

173. Mulligan quoted by Pike 1998: 83.

174. Fitzgerald to Police Commissioner 5/3/1885 notes that police patrolled through Jones' Boralga run 'interviewing the Deighton and Normanby Blacks' QSA COL/A422 1840/85.

175. Trezise 1968, 1971; 'Tramp' 1936: 27 refers to Aboriginal use of 'secluded mountains' of the Normanby River district as vantage points during the 'Palmer days'.

176. Mulligan quoted in Pike 1998: 82.

177. Mulligan quoted in Pike 1998: 83.

178. Mulligan quoted in Pike 1998: 94.

179. Cooktown Herald 5/4/1876; see also Reynolds 1982: 107; Corfield 1923; St George to Secretary Works and Mines 2/4/1874 QSA WOR/A83.

180. See also Reynolds 1982: 163-6. 
that Aborigines considered cattle 'their lawful prey', but pastoralists viewed raids on cattle as theft which caused them serious economic disadvantage. ${ }^{181}$

As always, the wet season hampered police and pastoral activities, providing safer conditions for Aborigines to move around. ${ }^{182}$ In 1890 Inspector Murray wrote that the owner of Lakefield Station had found large Aboriginal camps full of cattle bones in areas which could not be reached in wet weather. ${ }^{183}$ Murray called for additional troopers and advised against shifting the Laura Camp, in view of the scale of attacks on cattle around the Deighton and Laura. ${ }^{184}$ Another letter reported that the Lower Laura and Eight Mile detachments were working to recover stolen firearms which were being used by Aborigines to shoot cattle. ${ }^{185}$ This reference to Aboriginal use of guns appears to be most unusual, but police noted that it was becoming a very general thing for blacks to steal firearms now. ${ }^{186}$

Police were frustrated by the impact of cattle hunting and the endless conflict between pastoralists and Aborigines. A letter to the Police Commissioner recommends that the area north of the Mitchell River be made a territory for the Aborigines, because 'as long as whites are on their country there must be war between them'. Without increased police protection, 'the squatters will have to quit their holdings, it is much to be regretted that the Peninsula was ever opened for settlement'. ${ }^{187}$

Pastoralists continued to agitate for protection between the Laura River and the Coen, but the Police Commissioner blamed some of the problems on the pastoralists themselves: 'They keep very few hands on their runs to look after their stock and they generally look to the police to see that their cattle are not disturbed' ${ }^{188}$ In 1892 cattle hunting continued at Breeza and Lakefield stations and a trooper was speared. ${ }^{189}$ Pastoralists demanded the installation of a police camp at Coen or on the lower Normanby near Breeza station, but the District Inspector argued that Lower Laura provided a better base from which 'all that part of the country can be much easier reached. ${ }^{, 190}$ In 1894 the Travelling Inspector warned against closing Lower Laura as 'the Musgrave detachment would not be able to keep the Aboriginals in check in that large and broken tract of country extending from the Laura River to Princess Charlotte Bay - The Aborigines are very numerous'. ${ }^{191}$

In 1894 the typical work force on cattle stations in the Laura district included two or three Aboriginal workers described by whites as 'black boys'. ${ }^{192}$ The term 'black boy'

181. QVP vol II 1897; see also Reynolds 1982: 107.

182. See Whiteford to Inspector, Cairns 2/1/1911, QSA A/40348, Inspector Cairns - 26

183. Murray to Police Commissioner 6/6/1890 QSA A/41229, 7389/90; see also Balser et al, to Police Commissioner 29/7/1890 QSA A/41230, 8718/90.

184. Murray to Police Commissioner $2 / 8 / 1890$ QSA A41364, 8342/90.

185. Murray to Police Commissioner 6/6/1890 QSA A/41229, 7389/90.

186. Murray to Police Commissioner 2/8/1890 QSA A/41364 8342/90; note that Corfield 1923: 59 refers to the use of 'rusty rifles' by absconding Aboriginal troopers.

187. Murray to Police Commissioner 6/6/1890 QSA A/41229, 7389/90.

188. Seymour to Colonial Secretary 3/3/1891 QSA/A41229-48S 2344.91.

189. Fitzgerald to Police Commissioner 18/8/1892 QSA A/41229, 8427/92.

190. Murray to Police Commissioner 15/8/1890 QSA/A41229-48S, 8827/90.

191. Travelling Inspector to Police Commissioner 12/12/1893 QSA A/41364 149S, 12435/93.

192. Culpin 29/12/1893 in Mackeith 1987: 47. 
was defined by a contributor to the Queenslander's 1880 forum on race relations as 'servants who get no wages', a typical example of the 'loathsome and horrible system of dealing with our blacks'. ${ }^{193}$ Their fate was similar to that of other Aboriginal children and adults of the Cook district who were forced into situations of unpaid domestic and bush labour. ${ }^{194}$ Such people were characterised by police as 'semi-civilised', since they spoke English and had experienced life on the fringes of white society. ${ }^{195}$

The small number of Aboriginal workers on cattle stations reflected their mistreatment by pastoralists and the general hiatus in cross-cultural relations. It was not unusual for abused Aboriginal workers to abscond and/or seek revenge. ${ }^{196}$ Trezise recorded Caesar Lee Cheu's story of a 'Gugu Warra' man named 'Hero' who was exploited as a station worker, escaped, worked again and was flogged by a pastoralist. Hero speared the pastoralist and took to a life on the run. ${ }^{197}$ In 1890 a thirteen year old Aboriginal worker was charged with the murder of pastoralist Harry Jones. ${ }^{198}$ It was said that Jones 'worked the boy too hard and ... had threatened to shoot the lad'. ${ }^{199}$ The District Inspector, in discussing abuse of Aboriginal station workers, conceded that this 'in some way account(s) for the native hostilities'. ${ }^{200}$ The violent deaths of pastoralists Jones of Koolburra (formerly of Boralga), Donald Mackenzie of Lakefield, Ferguson of Mentana, E Watson of Pine Creek and Charles Massy of Lallah Rook were symptomatic of the bitter and protracted pastoral-Aboriginal conflict on Cape York Peninsula. ${ }^{201}$

\section{End of the 'wild time'}

Although Aboriginal groups had been able to adapt traditional lifestyles, making forays into resource rich areas, occupying remote locations, raiding huts and hunting stock, in the long term these strategies were unsustainable. The difficulties are reflected in reports of large, semi-permanent camps on the Laura, Deighton and Kennedy Rivers. In 1892 Millais Culpin described such a camp on the Laura River: 'About $1 / 4$ mile from here is the camping ground of a tribe of over $100^{\prime} .^{202}$ A photograph taken of Aboriginal men lining the Laura railway bridge c.1892 probably depicts occupants of this camp, as well as people who worked in Laura or on local cattle stations. ${ }^{203}$ The transitional state of Aboriginal society of the $1890 \mathrm{~s}$ is apparent in the mixed appearance of the group many of the men are holding spears, some are dressed in European clothing (Figure 9).

Pressures on Aboriginal people did not abate, as indicated by the Inspector of Police in 1894: 'If they (the blacks) commit depredations they will be punished and

193. Cited by Reynolds 1998: 120 , see also 108-37 for the Queenslander 'crusade'.

194. See Haviland and Hart 1998: 4; see also H Fitzgerald to Commissioner of Police 5/3/1885 QSA COL/A422, 1840/85 for evidence of such exploitation.

195. See Murray to Police Commissioner 6/6/1890 QSA A/41229, 7389/90; Whiteford to Lamond 4/5/1897 QSA COL/142.

196. See May 1983: 71.

197. Trezise 1969: 145.

198. May 1983: 71.

199. May 1983: 71 quoting the Queenslander 13 September 1890 .

200. Fitzgerald to Police Commissioner 5/3/1885 QSA COL/A422 1840/85.

201. See also Bolton 1972: 93; Loos 1982: 194-247 lists settler deaths caused by Aboriginal resistance in north Queensland.

202. Culpin 8/8/1892 in Mackeith 1987: 13.

203. JO Neg. 31561. 


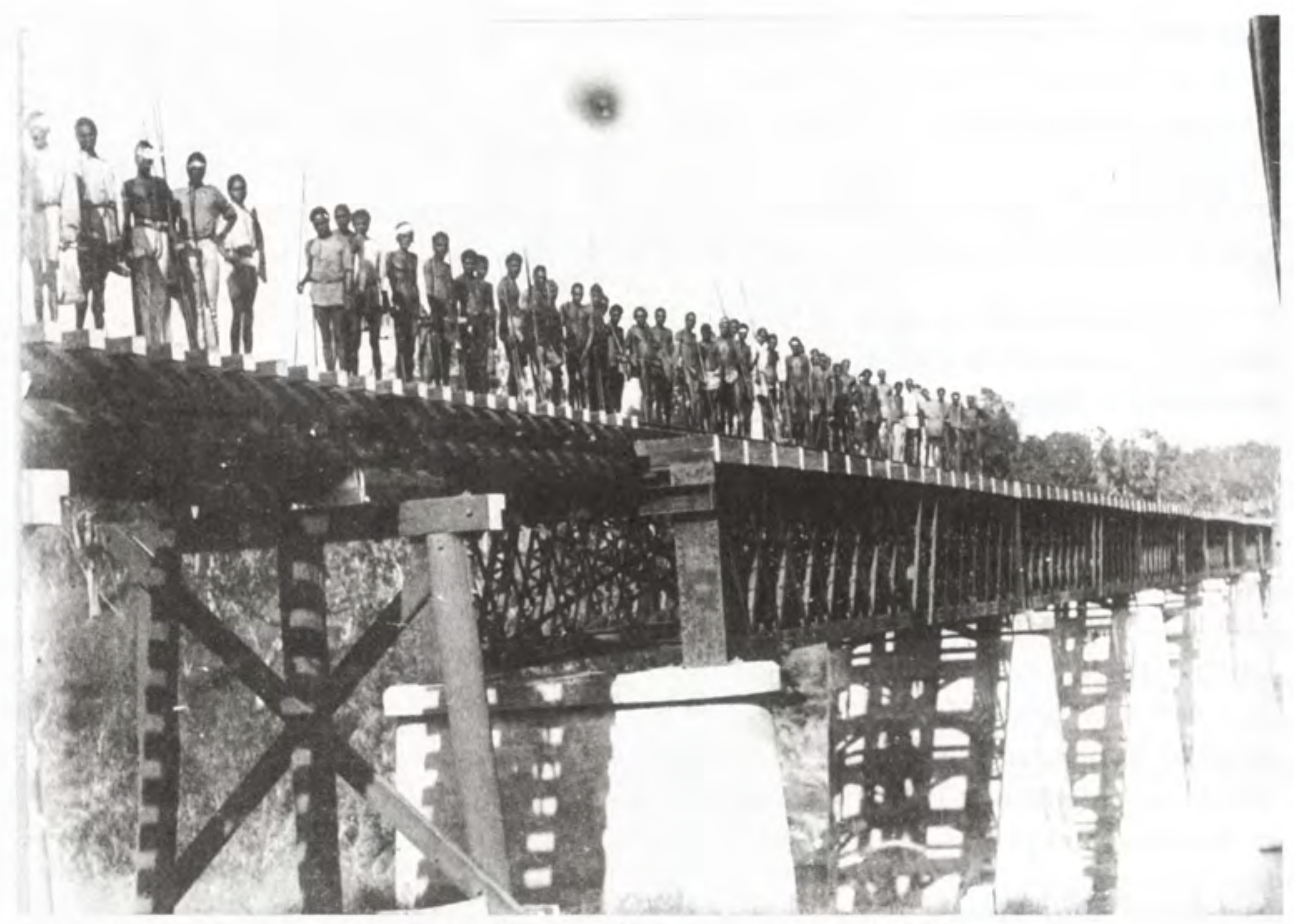

Figure 9: Laura railway bridge, 1892. John Oxley Library Neg. 31561

know it. ${ }^{204}$ As the longstanding government policy of 'dispersing' large groups of Aborigines was not abandoned until the late $1890 \mathrm{~s}^{205}$ it is not surprising that the river camps were fluid in composition and location. Aboriginal people evidently continued to move around in groups, joining river camps from time to time. This mobility is indicated in a petition of 1894 which complained of large numbers of Aborigines making periodic visits to Laura. ${ }^{206}$ One of the last records from Lower Laura reports a patrol to the Aboriginal camp on the Laura river, apparently in a futile search for labour for the sugar industry: 'There were very few blacks to be found and none suitable for plantations. $^{207}$

By the 1890s imported diseases were endangering Queensland's Aboriginal population. ${ }^{208}$ Venereal diseases which were apparent in Cooktown in the $1880 \mathrm{~s}^{209}$ were reported in 'outside' districts in the 1890s. For example, the newly appointed Police Commissioner Parry-Okeden noted signs in the Coen district of 'diseases that invariably follow the adoption of the vicious habits of the whites' ${ }^{210}$ Nevertheless, there were

204. Fitzgerald to Police Commissioner 26/2/94 QSA A/41364 149S, 94.2298 Cook.

205. Reynolds 2000: 119; see also Reynolds and May 1995.

206. Petition to Colonial Secretary 9/2/1894 QSA A/41364 149S, 02298/94.

207. Smith to Inspector Fitzgerald 6/4/1894 QSA A/41364 149S, 3588/94; see also Fitzgerald to Police Commissioner 6/3/1894 QSA A/41364 (021931/94).

208. Yarwood and Knowling 1982: 202.

209. Haviland and Haviland 1980.

210. QVP vol II 1897: 9. 
still groups of Aboriginal people who were able to maintain, under immense duress, relatively free-ranging lifestyles and possibly adequate standards of health and wellbeing into the 1890 s. $^{211}$ It is likely that health problems increased in association with the increasingly sedentary and impoverished conditions of the later fringe camps. ${ }^{212} \mathrm{By}$ 1913 for example, the camp on the Laura River had descended into poverty. ${ }^{213}$

Eventually, most Aboriginal people of the area 'came in' to camps on the fringes of Laura and other towns, or on local telegraph or cattle stations. ${ }^{214}$ However, for some Aboriginal people the process was delayed until after the turn of the century. In 1900 it was reported that Aborigines were still disturbing cattle, firing grass and camping on water holes on Butcher's Hill Station (on the upper Laura River). The groups were described as 'the Coco Minnies and the Coca Warras tribes (who) come over the head of the Deighton and from Maytown' ${ }^{215}$ Trezise noted that one Aboriginal family came in to Maitland Downs station possibly around $1910 .{ }^{216}$ Aboriginal elders informed Trezise that the area between the Laura and Deighton Rivers was the 'last stronghold' of wild Aborigines. ${ }^{217}$ Evidently the tradition of rock art in that area continued in this area after the turn of the century. ${ }^{218}$ There are no records of the fate of these resilient people, but Trezise wrote that 'In 1965 the informants were reluctant to enter this country in case some of these wild people still remained. ${ }^{219}$

Missions had appeared around Cooktown in the 1880s, but their operations were restricted by their inability to produce food and reluctance of Aborigines to come in. ${ }^{220}$ The Lutherans failed to extend their mission to the 'crowds' of Aborigines in the hinterland, even though they were inspired by this challenge. ${ }^{221}$ It is unlikely that Aboriginal clans of the Normanby-Laura area were affected by mission activities until the late 1890s, when large scale 'removals' to missions and reserves were authorised by the government. ${ }^{222}$ Around that time, the appointment of local trackers, awarding of king plates and distribution of rations to Aborigines on a regular basis represented a final systematic effort to bring remaining 'wild' Aboriginal people of this area under control. $^{223}$

211. Whiteford to Lamond 24/7/1897 POL/J20 10,634/97.

212. Reynolds 1978: 254 notes the uncertain food supplies and poor nutrition of fringe camps; Ethel Culpin in Mackeith 1987: 97 described the destitute nature of the occupants of the Laura camp in 1913.

213. Ethel Culpin in Mackeith 1987: 97 described the destitute nature of occupants of the Aboriginal camp at Laura in 1913.

214. Aboriginal Land Claim to Lakefield National Park 1996: 81.

215. Earl to Police Commissioner 3/3/1900 QSA A/41364. 05169/00.

216. See Trezise 1993: 153.

217. Trezise 1971: 25; see also Trezise 1969: 119.

218. Trezise 1971: 10 .

219. Trezise 1971: 25

220. Haviland and Haviland 1980.

221. Haviland and Haviland 1980: 128.

222. Under the provisions of the Aboriginals Protection and Restriction of the Sale of Opium Act 1897, see eg Fitzgerald 1982: 217-19.

223. Roth 1898: I; Lamond report on inspection of Laura Police Station 6/5/1897 PM

Commissioner of Police inward correspondence $05,884 / 97$, previous letter no. 147.97; 96.9571

Cook; Lamond to Police Commissioner 3/6/97 QSA POL/J20, 7104/97; Blake 1998: 61; see also Haviland and Hart 1998: 4. 


\section{Overview of conflict strategies}

Ross Fitzgerald identified 'white frontier attitudes and the relatively high Aboriginal population' as sources of the racial violence in north Queensland ${ }^{224}$ but the duration and ferocity of the conflict points to powerful motivations on both sides of the frontier.

A major consequence of 'white frontier attitudes' was the management of race relations by the Commissioner of Police. Another was the failure of police to conciliate with Aborigines or to contain the lawlessness of pastoralists and other new settlers. Although economic and demographic aspects of the frontier changed from 1873 to 1894, the policies of the government towards Aborigines failed to alter. Public complaints about alleged settler and police brutality aired in the Queenslander ${ }^{225}$ apparently had little impact on the Cook Police District. It is obvious that the distance from Brisbane (some 1500 miles or 2415 kilometres) enabled the government to ignore criticism of frontier policy for years. ${ }^{226}$

The unusual longevity of Lower Laura police camp was due to its strategic location across the mining, transport and pastoral frontiers. However, it is likely that problems created by isolation and geography undermined the efficiency of the police. ${ }^{227}$ As regular officers could not transfer to the mounted corps (although the reverse could occur) ${ }^{228}$ the limited staffing pool of the Native Mounted Police gives the impression of being isolated and overworked. Aboriginal resistance, debilitating local conditions, ill health and ongoing complaints of new settlers may have affected police morale.

In the role of overseeing the destruction of Aboriginal society, Lower Laura Native Mounted Police camp was partially successful, as some local clans were obliterated, and the pastoral industry prevailed, if precariously. In the 1890 s the sparse population of squatters struggled on, 'holding the land by a tenure scarcely more secure than that of the Aborigines themselves'. ${ }^{29}$ The substantial costs of maintaining protection led to serious suggestions that settlers abandon Cape York Peninsula. ${ }^{230}$

Hughes has concluded that 'no one can be sure exactly how many whites died' on the Cooktown transport frontier. ${ }^{231}$ It is equally difficult to quantify Aboriginal deaths over the colonial period. From 1873, unknown numbers of Aboriginal men, women and children of the Cook district were shot, captured, poisoned, sexually assaulted, infected with virulent diseases and/or exploited by police, teamsters, packers, miners, government officials, farmers, pastoralists and others. The economic base and assets of Aboriginal society were systematically destroyed.

224. Fitzgerald 1982: 209.

225. Queenslander 1 May 1880 to 3 July 1888; see also Rowley 1972: 168; Mulvaney 1989: 100-1; Reynolds 1998: 106-37.

226. See also Kirkman 1978.

227. See also Hughes 1978: 109 who noted that 'fever and desertion' impaired the efficiency of the Native Police.

228. Whittington 1964-65.

229. Bolton 1972: 93; Hughes 1978: 103 stated that 'perhaps if the settlement had been closer, the duration of Aboriginal resistance would have been shorter'.

230. See above; a similar recommendation appears in 1896, QSA A/41590 360.S 'WK' 29/7/1896.

231. Hughes 1978: 111. 
Reynolds correctly asserts that historical evidence of Aboriginal attitudes to the frontier is totally inadequate, ${ }^{232}$ but the Aboriginal position may be inferred in the nature and tenacity of Aboriginal resistance. The size and cohesion of the Indigenous population and the prosperity of local clans provided a basis for a bold and steadfast defence on several fronts (the transport corridors, new settlements and the gold fields). The profile of resistance to pastoralism indicates the capacity of clans to regroup and adapt while maintaining valued identities, customs and beliefs. Unlike on the Palmer goldfields where miners were scattered across the landscape, new settlers in the LauraNormanby area were mainly confined to the grassy lowlands and river valleys. Hence the proximity of 'wild', inaccessible country to which Aboriginal people were long connected, and the prevailing monsoon climate to which they were well adapted, were important factors which supported the Aboriginal defence. ${ }^{233}$ In a possibly associated strategy, casual attachment to semi-permanent river camps provided a means of maintaining continuity with age-old patterns of land use on resource-rich waterways as well as a degree of independence and nutrition. ${ }^{234}$

Rowley concluded that the process of Aboriginal people 'coming in' to European settlements could not occur until 'only dispirited groups remained'. ${ }^{235}$ This situation developed at Cooktown very early in the frontier period, ${ }^{236}$ while in the rugged Palmer area the process was delayed until after $1880 .{ }^{237}$ The timing was even later around the Laura River where groups of Aboriginal people continued to maintain a clandestine presence on pastoral holdings in the 1890 s and possibly later. Ultimately, integration with the cattle industry and local towns enabled many Aboriginal families to maintain their connections to land.

In attempting to compare 'cosmological landscapes' of European pastoralists with those of Indigenous people of Cape York Peninsula, Veronica Strang identified 'affective values' which characterise Kunjen engagements with land, for example: continuity of residence, cognitive encompassment of one area, collective identity, inalienable land ownership, cosmological structures related to local environment, economic sustainability and detailed local knowledge. ${ }^{238}$ This complex type of land tenure which has material as well as spiritual dimensions, ${ }^{239}$ sustained Aboriginal society throughout the colonial period.

\section{Historical significance of Boralga}

The Native Mounted Police network eventually vanished from Cape York Peninsula. The meagre material legacy is evident at Lower Laura, one of the most substantial and durable of its establishments.

\footnotetext{
232. See Reynolds 1972: 34.

233. Kirkman 1978: 130, citing Loos 1976 notes the influence of geography on the mining frontier; Evans 1999: 37 notes that Fraser Island provided a refuge to Aboriginal people of the Wide Bay district.

234. Reynolds 1978: 254 states that fringe camps which had access to the sea or large rivers 'had a much better chance of maintaining a reasonable level of nutrition and ... independence'.

235. Rowley 1972: 178.

236. Haviland and Haviland 1980: 124.

237. Kirkman 1978.

238. Strang 1997: 284-9.

239. Rigsby 1999: 963.
} 
'Brolga' remains a place in the landscape of local history and memory, with deeply felt connections to local people and the tracker and cattle station traditions. ${ }^{240}$ As a post-contact heritage place, the historic settlement of Boralga demonstrates a significant pattern of Queensland's colonial history, an epic story of Aboriginal resilience and the violent appropriation of Aboriginal lands. Boralga also testifies to the transience of frontier values and settlements and the significant challenges faced by new settlers. A few posts, graves and relics serve as a memorial of Queensland's failure to prevent another colonial war.

\section{Acknowledgements}

The author is grateful to George Musgrave, the late Mrs Musgrave, Tommy George, the late Mrs George, Danny Banjo, Roseanne George, Bruce Rigsby, Albert Lakefield, Paddy Bassani, Alice Buhrich, Victor Steffensen, Arthur Cole and Mike Morwood for their contributions. Staff at John Oxley and Fryer Libraries, Queensland State Archives, Queensland Museum, James Cook Museum, Australian Institute of Aboriginal and Torres Strait Islander Studies, Queensland Police Museum and Bill Kitson, Queensland Department of Natural Resources assisted in archival research. J Ruig and S Whiley provided access to private research. The Laura community project was funded by the Cultural Heritage Grants Program, Queensland Environmental Protection Agency. The author thanks anonymous referees for their comments and John Oxley Library and Queensland Department of Natural Resources and Mines for permission to reproduce photographs, plans and maps.

\section{References}

\section{Primary sources}

\section{Australian Institute of Aboriginal and Torres Strait Islander Studies Library}

Roth, WE 1898, Report [to the Commissioner of Police, Brisbane] on the Aboriginals occupying the hinter-land of Princess Charlotte Bay, together with a preface containing suggestions for their better protection and improvement.

\section{James Cook University Library}

Hann, W 1873, Copy of the diary of the northern expedition under the leadership of Mr. William Hann, Government Printer, Brisbane.

\section{John Oxley Library (JO)}

Jardine, F 1867, Narrative of the overland expedition of the Messrs. Jardine, from Rockhampton to Cape York, Northern Queensland, compiled from the journals of the brothers and edited by Frederick J Byerley, JW Buxton, Brisbane.

Hogg, JJ (no date) The Palmer goldfield: narrative of a pioneer miner (John Oxley Library OM91-100/1-206).

Cooktown Courier 25/1/1879.

Cooktown Herald 21/10/1874, 28/10/1874, 11/11/1874, 3/2/1875, 1/1/1876, 5/4/1876.

Queenslander 1 May 1880 to 3 July $1880 ; 2 / 1 / 1897$.

Photographic negatives: 57328, 158150, 61221, 66481, 66439, 66480, 31561. 


\section{Queensland Department of Natural Resources (DNR)}

Embley, JT 1883, Plan of run surveys Cook District. Traverse of Laura Normanby, surveyed by JT Embley, Licensed Surveyor.

\section{Queensland State Archives (QSA)}

A / 40117 File 1449 O'Connor, S Police Staff file.

A / 40310 Marrett, CB Police Staff file.

A/40348 Whiteford, J Police Staff file.

A/41229-48S 1 Coen Police Station (1890-1920).

A/41230 49S(1) Coen Police Station 1891-1937.

A/41364 Laura Police Station files.

A/41590 to $1899360 . S$ Highbury Police Station file.

A/41596 Frome Police Station file.

A/41614 441S Glendhu Police Station file.

A/44857 Tracker files.

COL/A422 Colonial Secretary's inwards correspondence.

COL/142 Correspondence and papers relating to the Queensland aborigines.

POL/J20 Distribution of rations to Aboriginals.

WOR/A83 General Correspondence Records 552.

\section{Queensland Police Museum (PM)}

Commissioner of Police inward correspondence file.

\section{University of Queensland Fryer Library}

Blue Book of Queensland 1873.

Meston, A 1896, A report on the Aborigines of Queensland. Government Printer, Brisbane.

Queensland Legislative Assembly Votes and Proceedings (QVP), Vol 1, 1875. Report of the Commissioner for Police for the year 1874.

QVP vol I, 1879, Report of the Commissioner for Police for the year 1878 .

QVP vol I, 1885, Report of the Commissioner for Police for the year 1884.

QVP vol II, 1897, Parry-Okeden (Commissioner of Police) Report on the North

Queensland Aborigines and the Native Police.

\section{Other references}

Aboriginal Land Claim to Lakefield National Park 1996, Report of the Land Tribunal established under the Aboriginal Land Act 1991 to the Hon. Minister for Natural Resources.

Anderson, C and R Robins 1988, 'Dismissed due to lack of evidence? Kuku-Yalanji sites and the archaeological record', in B Meehan and R Jones (eds) Archaeology with ethnography: an Australian perspective, Australian National University, Canberra: 182-205.

Binnie, JH 1944, My life on a tropical goldfield, Bread and Cheese Club, Melbourne.

Blake, T 1998, "Deported ... at the sweet will of the government": the removal of Aborigines to reserves in Queensland 1897-1939', Aboriginal History 22: 51-61. 
Bolton, G 1972, A thousand miles away: a history of north Queensland to 1920, Jacaranda Press, Brisbane.

Bradford, JR 1961-62, 'The Cape York expedition of 1883', Journal of the Royal Historical Society of Queensland 6(4): 1014-28.

Brady, D, C Anderson and B Rigsby 1980, 'Some of us are still alive: the Palmer River revisited', Australian Institute of Aboriginal Studies Newsletter 13: 32-6.

Brady, EJ 1924, The land of the sun, Edward and Arnold, London.

Carron, WM 1849, Narrative of an expedition undertaken under the direction of the late Mr. Assistant Surveyor E.B. Kennedy for the exploration of the country lying between Rockingham Bay and Cape York, facsimile edition (1996), Corkwood Press, Bundaberg.

Cilento, $\mathrm{R}$ and C Lack 1959, Triumph in the tropics: an historical sketch of Queensland, Smith and Paterson, Brisbane.

Cole, N 1995, 'Rock art in the Laura Cooktown region, S.E. Cape York Peninsula', in M Morwood and D Hobbs (eds) Quinkan prehistory: the archaeology of Aboriginal art in S.E. Cape York Peninsula, Australia Tempus 3, Anthropology Museum, University of Queensland, St Lucia: 51-70.

- 1998, 'Eel and Boomerang: an archaeological study of stylistic variation in rock art of the Laura region', PhD thesis, James Cook University, Townsville.

— 1999, Field notes, Laura oral history project.

Cole, N, G Musgrave and L George with T George and D Banjo 2002, 'Community Archaeology at Laura, Cape York Peninsula', in S Ulm et al. (eds) Barriers, borders and boundaries: proceedings of the 2001 Australian Archaeological Association Annual Conference, Tempus 7, Anthropology Museum, University of Queensland, St Lucia: 137-51.

Corfield, WH 1923, 'Reminiscences of north Queensland', Journal of the Royal Historical Society of Queensland 2(2): 81-96.

Evans, R 1999, Fighting words: writing about race, University of Queensland Press, St Lucia.

Evans, R, K Saunders and K Cronin 1988, Race relations in colonial Queensland: a history of exclusion, exploitation and extermination, University of Queensland Press, St Lucia.

Fitzgerald, R 1982, A history of Queensland: from the Dreaming to 1915, University of Queensland Press, St Lucia.

'GP' 1942, 'The Koolburra tragedy: shooting of Harry Jones', Cummins and Campbell's Monthly Magazine October: 29, 31.

_ 1944, 'Battles with Blacks: Mitchell River and Battle Camp', Cummins and Campbell's Monthly Magazine July: 5, 37.

- 1946, 'On the road to Eldorado - and tragedy: looking back seventy years', Cummins and Campbell's Monthly Magazine January: 19, $20,23$.

Haviland, J 1979, 'Guugu Yimidhirr', in RMW Dixon and BJ Blake (eds) Handbook of Australian languages, Australian National University Press, Canberra: 27-180.

Haviland, J and Haviland L 1980, 'How much food will there be in heaven? Lutherans and Aborigines around Cooktown to 1900', Aboriginal History 4(1-2): 119-49. 
Haviland, JB and R Hart 1998, Old Man Fog and the last Aborigines of Barrow Point, Crawford House Publishing, Bathurst.

Hill, WRO 1907, Forty-five years experience in north Queensland 1861-1905, H Pole \& Co, Brisbane.

Holthouse, H 1985, S'pose I die: the story of Evelyn Maunsell, Angus and Robertson, North Ryde (Sydney).

Hughes, I 1978, 'A state of open warfare: frontier conflict in the Cooktown area', in $\mathrm{H}$ Reynolds (ed) Race relations in north Queensland, History Department, James Cook University, Townsville: 99-117.

Jack, RL 1922, Northmost Australia: three centuries of exploration, discovery and adventure in and around the Cape York Peninsula, Queensland, vols I and II, George Robertson \& Co, Melbourne.

Johnston, W 1977, 'A record of deaths which occurred during the first year of the Palmer', Cairns Historical Society Bulletin 207.

Kidd, R 1997, The way we civilise, University of Queensland Press, St Lucia.

Kirkman, N 1978, 'A snider is a splendid civilizer: European attitudes to Aborigines on the Palmer', in H Reynolds (ed) Race relations in north Queensland, History Department, James Cook University, Townsville: 119-43.

Lamond, HG 1949 'Native Mounted Police', Walkabout 15(11): 31-2.

Loos, N 1982, Invasion and resistance: Aboriginal European relations on the north Queensland frontier 1861-1897, Australian National University Press, Canberra.

Mackeith, F 1987, 'Introduction', in F Mackeith (ed) Letters from Laura: a bush schoolmaster in Cape York Peninsula 1892-1896, History Department, James Cook University, Townsville: 111.

May, D 1983, From bush to station: Aboriginal labour in the North Queensland pastoral industry 1861-1897, History Department, James Cook University, Townsville.

McConnell, U 1930, 'The Wik-Munkan Tribe', Oceania 1: 97-125.

McKenna, M 2002, Looking for Blackfella's Point: an Australian history of place, University of New South Wales Press, Sydney.

McKenzie, $\mathrm{K}$ and C Cooper 2001, 'Eyewitness? Drawings by Oscar of Cooktown', in I McCalman, A Cook and A Reeves (eds), Gold: forgotten histories and lost objects of Australia, Cambridge University Press, Cambridge: 157-63.

Morgan, G, J Terrey, T Bean and M Abel 1995, 'The biophysical environment', in M Morwood and D Hobbs (eds) Quinkan prehistory: the archaeology of Aboriginal art in S.E. Cape York Peninsula, Australia, Tempus 3, Anthropology Museum, University of Queensland, St Lucia: 5-17.

Morwood, M 1995, 'Aboriginal ethnography, SE Cape York Peninsula', in M Morwood and D Hobbs (eds) Quinkan prehistory: the archaeology of Aboriginal art in S.E. Cape York Peninsula, Australia, Tempus 3, Anthropology Museum, University of Queensland, St Lucia: 33-9.

Morwood, M and D Hobbs 1995, 'Conclusions', in Morwood, M and D Hobbs (eds) Quinkan prehistory: the archaeology of Aboriginal art in S.E. Cape York Peninsula, Australia, Tempus 3, Anthropology Museum, University of Queensland, St Lucia: 178-85. 
Mulvaney, DJ 1989, Encounters in place: outsiders and Aboriginal Australians 1606-1985, University of Queensland Press, St Lucia.

Palmer, E 1983, Early days in Queensland, Angus and Robertson, Sydney, (Queensland Classics Edition).

Patz, E 1982, 'A grammar of the Kuku Yalanji Language of North Queensland', PhD thesis, Australian National University, Canberra.

Pearce, H 1998, 'Lakefield National Park Cultural Heritage Report vol 1 Old Laura Homestead Conservation and Management Plan', Cultural Heritage Branch, Department of Environment and Heritage, Brisbane.

- 2000, 'Lakefield National Park Cultural Heritage Report vol 2 Lakefield Laura Station historical heritage places survey', Cultural Heritage Branch, Environmental Protection Agency, Brisbane.

Pike, G 1998, On the trail of gold: the story of James Venture Mulligan north Queensland's greatest prospector explorer, an autobiography quoted by Glenville Pike, with commentary, Glenville Pike, Mareeba.

Pohlner, H 1986, Gangurru, Hope Vale Mission Board, Milton.

Queensland Police Department 1982, The history of the Native Mounted Police.

Queensland State Archives 1994, Records guide vol 1 A guide to Queensland Government records relating to Aboriginal and Torres Strait Islander peoples, Queensland State Archives and Department of Family Services and Aboriginal and Islander Affairs, Government of Queensland, Brisbane.

Reynolds, H (ed) 1972, Aborigines and settlers: the Australian experience 1788-1939, Cassell Australia, Stanmore (NSW).

Reynolds, H 1978, 'Fringe camps in nineteenth century Queensland', in Lectures on North Queensland History, 3rd series, James Cook University, Townsville: 247-60.

1982, The other side of the frontier: Aboriginal resistance to the European invasion of Australia, Penguin, Ringwood (Melbourne).

—_ 1998, This whispering in our hearts, Allen and Unwin, St Leonards (Sydney).

2000, Black pioneers, Penguin, Ringwood (Melbourne).

Reynolds, H and D May 1995, 'Queensland', in A McGrath (ed) Contested ground: Australian Aborigines under the British Crown, Allen and Unwin, St. Leonards (Sydney): 168-201.

Rigsby, B 1980, 'The language situation on Cape York Peninsula: past, present and future', in Reef, rainforest, mangroves, man, Wildlife Preservation Society of Queensland, Cairns: 5-7.

1997, 'Structural parallelism and convergence in the Princess Charlotte Bay languages', in P McConvell and N Evans (eds) Archaeology and linguistics: Aboriginal Australia in global perspective, Oxford University Press, Melbourne: 16978.

1999, 'Aboriginal people, spirituality and the traditional ownership of land', International Journal of Social Economics 26(7-9): 963-73.

- 2002, 'Kuku Thaypan, introduction', unpublished MS held by the author.

- 2003, 'The languages of the Quinkan and neighbouring region', Unpublished report prepared for the Quinkan Cultural Centre. 
Roth, W 1901, 'Food, its search, capture and preparation', North Queensland Ethnography Bulletin 3, Government Printer, Brisbane.

- 1910, 'Social and individual nomenclature', North Queensland Ethnography Bulletin 18, Government Printer, Brisbane.

Rowley, CD 1972, The destruction of Aboriginal society, Penguin, Harmondsworth.

Ruig, J and M Morwood 1995, 'History of SE Cape York Peninsula', in M Morwood and D Hobbs (eds) Quinkan prehistory: the archaeology of Aboriginal art in S.E. Cape York Peninsula, Australia, Tempus 3, Anthropology Museum, University of Queensland, St Lucia: $40-50$.

Sharp, L 1939, 'Tribes and totemism in north-east Australia', Oceania 9(3): 254-75.

- 1952, 'Steel axes for stone age Australians', in EH Spicer (ed) Human problems in technological change: a casebook, Russell Sage Foundation, New York: 69-90.

Shay, J and B Shay 1995, Forgotten victims: the story of the Strau family, 2nd edn, Cooktown and District Historical Society.

Sommer, B 1976, 'W.E. Roth's Peninsula vocabularies', in P Sutton (ed) Languages of Cape York, Australian Institute of Aboriginal Studies, Canberra: 127-38.

Stephens, SE 1972, 'The Palmer Road in 1972', Caims Historical Society Bulletin 154.

Strang, V 1997, Uncommon ground: cultural landscapes and environmental values, Berg, Oxford.

Strike, B 1988, 'John Hogsfleisch, Palmer River pack horse mailman', Cairns Historical Society Bulletin 337.

Sundowner 1947, 'Around the campfire', North Queensland Register 13 September.

Thomson, D 1972, Kinship and behaviour in north Queensland, a preliminary account of kinship and social organization on Cape York Peninsula, edited by HW Scheffler, Australian Institute of Aboriginal Studies, Canberra.

'Tramp' 1936, 'Bushwhacks', Cummins and Campbell Monthly Magazine September: 26-7.

Trezise, P 1968, 'Aboriginal cave paintings: sorcery versus snider rifles', Royal Queensland Historical Society Joumal 8(3): 546-51.

— 1969, Quinkan country, Reed, Sydney.

- 1971, Rock art of south-east Cape York Peninsula, Australian Institute of Aboriginal Studies, Canberra.

— 1985, 'Crocodile 1 Gallery, Laura', Rock Art Research 4(2): 124.

- 1993, Dream road, Allen and Unwin, St Leonards (Sydney).

Whittington, A 1964-65, 'The Queensland native mounted police', Royal Queensland Historical Society Journal 7(3): 508-20.

Yarwood, AT and MJ Knowling 1982, Race relations in Australia: a history, Methuen, Sydney. 